\title{
'Non-friction reading: Licensing requirements for e-book lending in New Zealand public libraries'
}

\author{
by
}

\section{Amy Joseph}

\begin{abstract}
Submitted to the School of Information Management,
Victoria University of Wellington in partial fulfilment of the requirements for the degree of Master of Information Studies
\end{abstract}

\section{June 2013}

This work is licensed under a Creative Commons

Attribution-ShareAlike 3.0 New Zealand License 


\begin{abstract}
Research problem: Libraries face many challenges as they strive to provide e-books to their members, often caused by less-than-ideal licensing conditions, or publishers who will not yet license their titles to libraries for lending. This research project, developed in conjunction with a National Library of New Zealand initiative investigating collaborative ebook procurement for libraries, surveyed New Zealand public libraries in order to discover what elements of existing and proposed models would best meet the needs of their users. Methodology: a link to an online survey was emailed to public library managers, who were asked to complete the survey or delegate it to an appropriate staff member.

Results: Valid responses were received from 34 of the 67 library systems contacted (response rate $=50.8$ ). New Zealand public libraries are anticipating a large increase in spending on the provision of e-books, with the growth in spending on e-books set to outstrip growth in spending on other e-resources. They show a strong preference for perpetual access licenses, and generally tend to favour licenses that allow for control over title selection and predictability over budgets. They are concerned with system integration and would ideally like to see e-books from all their chosen vendors available through one interface that integrates with their catalogues. Libraries would like to see more New Zealand content available, and access to library e-book lending on all devices their users may choose to use.
\end{abstract}

Keywords: e-books, public libraries, licenses, New Zealand. 


\section{TABLE OF CONTENTS}

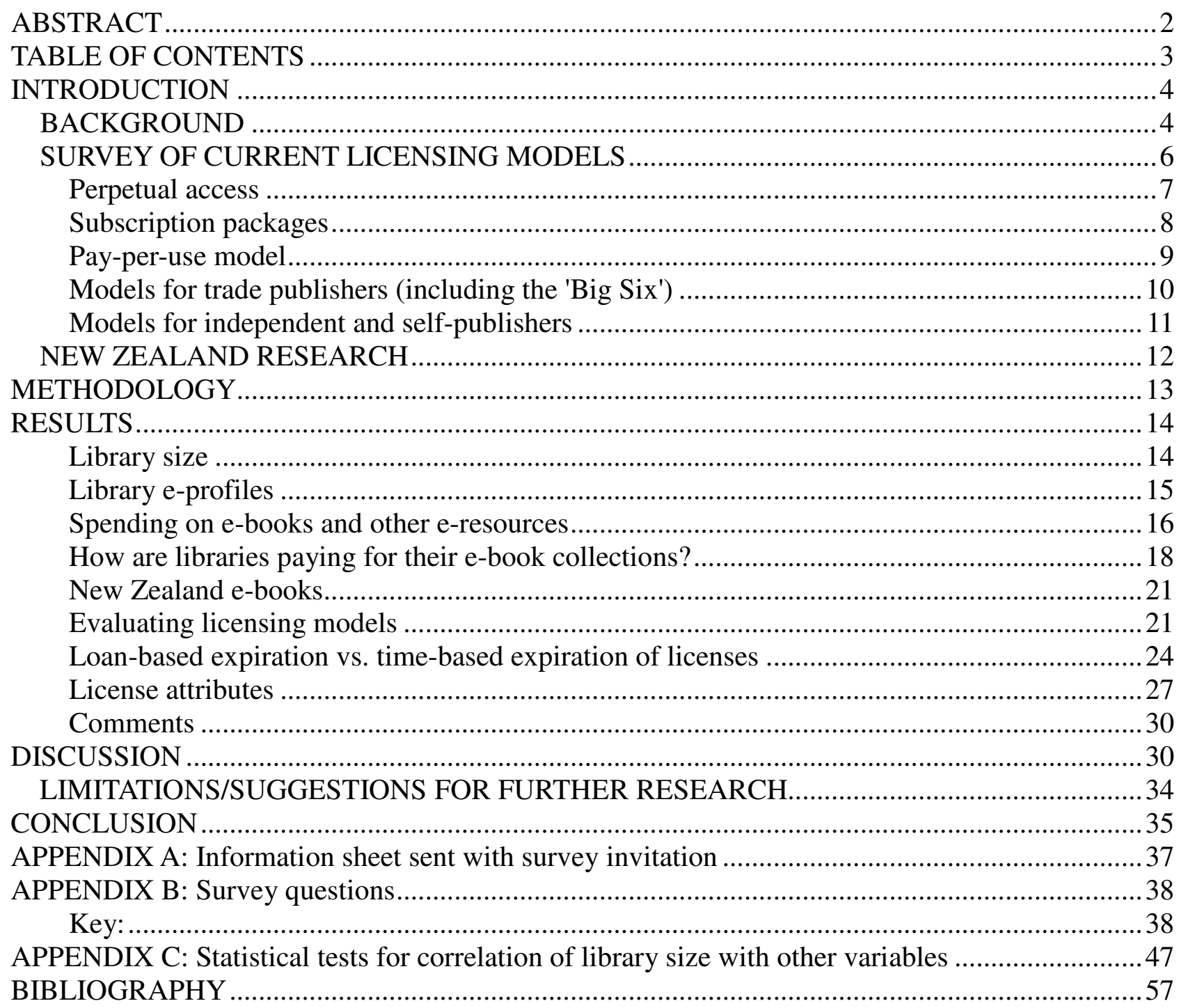




\section{INTRODUCTION}

The National Library of New Zealand (NLNZ) is currently involved in an initiative to work with public and school libraries, publishers, booksellers and authors to improve access to e-books via New Zealand libraries. The scope of the initiative is to explore opportunities to provide aggregated access to e-book content to New Zealanders through New Zealand public libraries and schools whilst recognising the rights of the producers and distributors. It is being led by the Collaborative Services team at NLNZ, which already does similar work in facilitating access to other electronic resources as the lead agency for the EPIC (Electronic Purchasing in Collaboration) consortium.

This research project is contributing to the NLNZ initiative by exploring licensing practices currently in use around the world for the provision of e-books in libraries, and surveying libraries to discover what elements of these models would meet the need of users in the New Zealand context. To ensure that the project is of a manageable scope, it is focused on e-book licensing for public libraries.

The objective of the study is to provide data on the needs of public libraries to the NLNZ ebooks initiative (and to other parties currently working in this area, such as publishers, vendors and LIANZA's Standing Committee on Digital Content and E-lending in Libraries). The project was developed in conjunction with NLNZ staff working on the initiative, and aims to identify the elements of potential licensing models most valued by New Zealand public libraries, and the degree of tolerance to limitations and friction imposed by such models in order to meet the needs of other stakeholders such as publishers and authors.

\section{BACKGROUND}

The spectacular growth in e-readers (e-ink devices, tablets and other mobile devices) and consequent rise in e-book consumption in recent years has led to an increasing need for libraries to facilitate access to e-books for educational and recreational use. For the purposes of the NLNZ-led initiative, an e-book is defined as "a text and/or image based publication in digital form produced on, published by, and readable on computers and other digital devices. E-books may be digitised versions of print books or born digital content made available electronically for reference or reading. They may be held locally or on a remote server and come in a range of file formats." 
Libraries cannot simply purchase copies of the e-books they wish to have in their collections and then lend those copies to their members, as has long been the model for print materials. Purchasers of e-books are typically buying licences to access content rather than the content itself, and publishers can elect not to make their material available for licensing to potential customers, such as libraries. Libraries are therefore not free to purchase and lend e-books as they have traditionally been free to do with print books under the right of first sale.

From the consumer's perspective, there does not have to be much difference between buying an e-book and checking one out from a library website (Grigson, 2011). There is no need to ensure that the book is available at an appropriate branch and to request its transfer if it is currently being held elsewhere in the system; to visit the branch to collect the book; or to return it to the branch before the end of the loan period or face paying late fines. There is no technical reason for the book to be unavailable if checked out by another user: one file could be copied and distributed to any number of users, anywhere in the world. There may also less status to be gained from purchasing your own copies of books: possession of the required hardware is more likely to be the source of status for e-book consumers.

Publishers are therefore concerned that a comprehensive library lending scheme could have severe adverse effects on their sales to the consumer market. They have responded to this threat with varying strategies: choosing not to make their titles available to libraries, making them available at a much higher price and/or after an embargo period, and imposing licensing conditions that create artificial 'friction' in the lending process. Publishers are currently at the stage of experimenting with the exact nature of these conditions.

In some respects the models that are available for library e-books are based on the existing models for lending print books in libraries - a copy can only be lent to one user at a time, and licenses might expire after a set number of loans in order to mimic the way in which a print book wears out and needs to be replaced. The recent Independent Review of E-Lending in Public Libraries in England, commissioned by the Department for Culture, Media and Sport, recommended accepting these sorts of limitations in order to establish arrangements that publishers and authors are happy with as well as libraries and their users, going as far as saying, "As far as is possible, the digital loan of a book should emulate its printed counterpart." However, other commentators are arguing that libraries 
and publishers should be using this transitional time to experiment more creatively with new models not necessarily based on the old print paradigm.

The American Library Association's Digital Content \& Libraries Working Group argues that "while business models [for library e-book lending] will continue to evolve, models that are explored in the year ahead may well pave the way to the models of the future. It is therefore important that libraries negotiate aggressively for the most favorable and flexible terms possible" (2012, p1). While the NLNZ initiative is trying to take a less adversarial stance towards publishers and distributors, NLNZ is one of several national-level library advocates which agrees that the next few years will be crucial in establishing the future environment for library e-book lending: similar projects are currently being carried out by equivalent stakeholder groups in Canada and the UK, for example.

O'Brien, Gasser, and Palfrey (2012) observed that "stakeholders from both sides of the debate noted that it would be difficult to imagine 'frictionless' arrangements, given the cannibalization concerns that cause many publishers to choose not to offer access to ebook titles. However, the key may lie in understanding how to weigh the types of friction against one another or which types of friction should be considered key design features in lending arrangements" (p25).

If it is generally agreed that it is acceptable to impose some forms of friction on library ebook licensing and lending, what conditions are most acceptable for publishers, authors, libraries and readers?

\section{SURVEY OF CURRENT LICENSING MODELS}

E-books are usually licensed to libraries via third-party vendors who act as distributors and platform hosts. These vendors license materials from publishers and then sub-license these to libraries. Libraries may sub-license materials via one vendor from a range of different publishers, and the licensing conditions may vary from title to title depending on the terms of the original licenses from the publishers to the vendor. 
The initial licensing contract between the publisher and the distributor sets forth the legal terms and conditions ... under which the distributor can sublicense the e-books to libraries. For example, the agreement may specify whether the ebook files are to be protected by DRM [Digital Rights Management], the price at which the distributor can sublicense each copy, sublicense expiration periods, whether the e-book can be printed, and so on. The distributor is legally obligated to follow the terms of this license, and cannot sublicense rights to libraries that exceed the rights the publisher has granted. ... Although the distributor cannot grant more rights to libraries than the publisher has granted to the distributor, the distributor may choose to grant fewer rights or impose additional restrictions on how the e-book may be accessed and used. For example, the distributor may specify which software must be used to access the e-books, the structure of fees (in addition the price of the e-book specified by the publisher), and whether the e-book may be downloaded by patrons or viewed only through an Internet browser.

O Brien, Gasser, and Palfrey (2012, p12).

\section{Perpetual access}

Perpetual access licensing is the model that is most similar to the models that have traditionally applied to libraries' print collections, even though the files are typically hosted on third-party servers rather than owned by the library - hence 'perpetual access' rather than ownership.

Lending conditions imposed by these licenses tend to mimic traditional print models: each copy purchased by library can only be checked out to one patron at a time, and it is 'returned' after a set loan period (ie. the lent copy is deleted from the patron's device, and the title becomes available to others via the library's e-book platform again). As with print copies, patrons can join a hold queue when demand exceeds supply, and libraries may choose to purchase more copies of popular titles.

Libraries may have to pay ongoing platform maintenance fees in addition to the cost of purchasing each title, and the 'perpetual' access may be lost if the library chooses not to continue with the distributor.

A variation on perpetual access is the leasing of specific titles, with lease periods based on time (eg. Penguin) or usage (eg. HarperCollins - see the outline of current 'Big Six' licensing conditions, below). Besen \& Kirby (2012) point out that limitations based on number of simultaneous users or total number of loans could be advantageous to smaller public library systems if it means that publishers charge less than they would for less restrictive conditions. Limitations based on time would be relatively more advantageous to 
large libraries, as they are likely to provide access to more users during a given time period than a smaller library.

Perpetual access is the model used by Overdrive, currently the globally-dominant provider of e-book access for public libraries. Overdrive hosts over 1 million titles from 1000 publishers, including major publishers such as Random House and HarperCollins. According to their website, they provide services to over 19,000 libraries worldwide (including public, school and tertiary libraries). The licensing conditions that apply to ebooks made available via the Overdrive platform can differ from publisher to publisher, and not all major publishers license materials to Overdrive.

Although not currently available in New Zealand, 3M and Baker \& Taylor compete with Overdrive in some overseas markets with similar library e-book lending platforms.

\section{Subscription packages}

Subscription packages tend to be more popular for school and tertiary libraries than for public libraries, as there is less choice about the titles included in the package. Libraries purchase access to a database of titles for a set period of time (eg. annually). If they do not renew their subscription then they loss access to the titles. This model is primarily used for reference materials, from vendors such as Gale and EBSCO. The cost per use may be high as the subscription price is often calculated based on the total library population. The subscription model may allow for simultaneous access for multiple users, although libraries will usually have to pay more for this feature. Subscription packages currently tend not to include front-list titles, making them less suitable for public library use.

Public Library Online offers annual subscriptions of themed packages (called 'shelves') to UK public libraries, and allows concurrent access for library members. The cost is based on population served by the library and number of shelves subscribed to. Readers must access the content from a device that has an Internet connection (books cannot be downloaded or transferred from another device) and supports Adobe Flash, a declining technology that is being replaced by HTML5 and is not supported on iOS or Android systems. However, Public Library Online say they are "working on delivering to all devices available on the market". 


\section{Pay-per-use model}

Libraries pay for access to database of titles (as with subscription model, but at a lower initial cost), then pay rental fees for copies loaned to patrons. This can be more economical as the library only pays for content that users consume, but it may be harder to predict budgets. Libraries can place a cap on the number of loans they pay for, and then decide whether to budget for more use, or wait for the cap to reset (eg. annually). Pay-peruse models can include the option to trigger a perpetual access purchase if demand is high enough (eg. triggered by a certain number of holds). Pay-per-use and related patrondriven acquisition models have potential for huge savings for academic libraries, although there are concerns that they could lead to unbalanced collections (Kolowich, 2012). EBL is a leader in this model for academic and reference materials, and allows a free window of time in which potential users can browse a title before a rental or purchase is triggered (EBL was purchased by ProQuest in January 2013).

Freading offers a metered pay-per-use system for public libraries based on a token system. Members of libraries that subscribe to Freading are given a weekly allotment of tokens that are spent to borrow books or renew loans. Loans may cost four, two or one tokens (the cost is set by the publisher, and tends to be based on how new the book is). Unused tokens expire after a month. Tokens used by members cost the library US $\$ 0.50$ each. Libraries can provide access to Freading's entire catalogue, and simultaneous use by multiple patrons for individual titles is allowed.

Danish public libraries have negotiated agreements with over fifty Danish publishers to provide lending access to Danish language e-books on a pay-per use basis. The more the title is borrowed, the lower the fee to the library. New releases have higher fees than ebooks over a year old. Individual libraries set number of e-books patrons may borrow and lending periods. Patrons are also provided with the option to buy the books, with the profits from the sale split between libraries and publishers ('New Zealand e-book initiative project approach', 2012).

The model currently offered by New Zealand company Wheelers (the major alternative to Overdrive for New Zealand public libraries) is a hybrid of perpetual access and pay-peruse: Wheelers hosts e-content rather than selling it to libraries to host on their own servers, but access for each e-book is purchased rather than leased (ie. libraries don't have to make an ongoing financial commitment to retain access to the titles they buy). A 
small additional fee is imposed per loan (currently 14 cents). Libraries can set the number of simultaneous loans per title, and Wheelers also allows libraries the option of charging rental fees for certain content like bestsellers.

\section{Models for trade publishers (including the 'Big Six')}

Recent commercial fiction is the mainstay of public library circulation, but is still lacking in library e-book offerings, as evident when comparing the Neilson top 10 Bestsellers of 2011 to the e-book holdings of three New Zealand public libraries - Tauranga via Wheelers, Wellington via Overdrive, and the Northern Overdrive consortium Nove-L. Tauranga had just one title from the Overall Adult Fiction Top 10 (Jodi Picoult's Sing You Home), and no titles from the New Zealand Adult Fiction Top 10. Nove-L had Sing You Home and Kate de Goldi's The 10pm Question from the New Zealand list. The best performer was Wellington, who had those two titles as well as Lesley Pearse's Belle from the Overall list. None of the three sampled libraries had any current Top 10 International Fiction (Adults) or New Zealand Fiction (Adults) in their e-books selections (sampling conducted in October 2012).

Major commercial publishers are still in the process of establishing models for providing ebooks to libraries. So far not many solutions have been implemented that both publishers and libraries find satisfactory, as exemplified in the vocal discontent of those in the international library sector to the efforts of the 'Big 6' publishers:

HarperCollins: 26 loan limit, after which books must be repurchased at discounted price. Libraries expressed outrage when this policy was introduced, but it is now seen as one of the more constructive solutions relative to others on the market (although most still consider 26 loans per copy to be too low).

Random House: libraries retain perpetual access of e-books they purchase, and eeditions are available simultaneously with the print release. However, Random House recently increased prices by factors of 2-3 times the hardcover list price for libraries.

Penguin: removed its titles from Overdrive after the distributor established a partnership with Amazon that redirected borrowers with Kindle devices to Amazon's website to complete the loan. ${ }^{1}$ Penguin now offers e-books for sale to libraries via $3 \mathrm{M}$ or Baker \&

1 Incompatibility with Kindle e-readers is a huge stumbling block for library e-book lending: Kindle boasts a huge share of the e-reader market, and most available library lending platforms are not compatible with Kindle's proprietary software. In New Zealand, neither Overdrive nor Wheelers offer loans for Kindle e-ink readers (although Amazon's tablet device, the Kindle Fire, allows third-party apps and is therefore compatible with more library lending platforms than the company's e-ink readers). 
Taylor, with purchases expiring after one year. In March 2013 it dropped the policy of embargoing library e-books sales for six months after the hardcover release. Its titles are still not available for Kindle e-readers.

NB. Random House and Penguin have recently merged; at this stage it is too early to tell what this will mean for their respective library e-book strategies.

Hachette: e-book versions of books published since 2010 are not available to libraries, and in 2012 Hatchette raised prices drastically on backlist titles. It has recently launched a pilot to experiment with supplying newer titles.

Macmillan: launching a pilot program selling the backlist of its Minotaur mystery and crime imprint to libraries. Licences will expire after the earlier of two years or 52 loans.

Simon \& Schuster: the last of the big six to tackle library lending, Simon \& Schuster launched a one year pilot program in New York in April 2013. It is making its full front list and back list available for an unlimited number of loans (although 'copies' can only be lent to one borrower at a time, and the purchases are currently set to expire at the end of the pilot period). The pilot includes links for library users to purchase titles directly from the publisher (with a share of the proceeds going to the referring library), and will collect data on whether library availability increases purchase demand.

\section{Models for independent and self-publishers}

As libraries tend to have their e-lending platforms maintained by third parties, it may not be a straightforward matter for small publishers and authors to sell their titles directly to libraries. Self-publishing platform Smashwords allows authors to opt in to the packages they provide to libraries, and allow authors to set the prices they charge libraries to purchase their titles. The most prominent model of libraries building their own platforms in order to provide users with titles from small publishers and self-published authors is Douglas County Libraries (DCL) in Colorado. DCL buys material that they host on their own servers, and then lend via their own platform (which uses Adobe Digital Editions, the same DRM software used by many commercial library e-book distributors). In June 2013 they announced a partnership with OdiloTID to facilitate direct sales from publishers to libraries (at time of writing it was unclear whether libraries would take ownership of e-book files or not). NLNZ or another party could potentially buy into a similar system developed by an external vendor, or develop their own in order to facilitate the sale of material from independent and self-publishers to New Zealand libraries. 


\section{NEW ZEALAND RESEARCH}

In 2011, New Zealand publishing company Bridget Williams Books (BWB) conducted a survey of New Zealand libraries when considering the development of an e-library product (BWB started making its titles available for libraries via Wheelers, ebrary and EBL in 2013). They received 120 responses from public, tertiary, school and special libraries. Thirty-three percent of respondents were from public libraries, but the results were not presented by sector. Fifty-five percent said that their library spent none of their acquisitions budget on e-books in 2011. Less than two percent expected to spend no money on ebooks in three years time, with 41.5 percent predicting that at least ten percent of their acquisitions budget would be spent on e-books within that time. The survey found that very few respondents were able to identify preferred vendors for e-books, and those that could commonly gave consortia access as a reason for preferring a given vendor. Vendors in use at the time of the survey were heavily weighted towards the academic sector, which was quicker to shift towards e-books than the public library/consumer market.

Survey respondents were asked which business models they preferred, and 'purchase with perpetual access' was the clear favourite: $\mathbf{4 7 . 7}$ percent rated this model as 'Very acceptable' with a further 24.4 percent rating it as 'Acceptable'. Annual subscriptions and patron-driven acquisition were reasonably popular models, while pay-per-use was seen as 'Unacceptable' by 37.2 percent.

BWB noted that respondents with existing e-book collections tended to be more forgiving about DRM provisions and other restrictions, which suggests that libraries shift to a more pragmatic position once they start dealing with the realities of providing e-books in the current environment. The survey was conducted before three regional consortia were established with Overdrive, and before Wheelers launched in the library e-book market in 2011 only three of the 66 local authority Public Library networks provided access to ebook collections; by the end of 2012 that had expanded to 57 public library networks (internal NLNZ e-book initiative document, 2013). The LIANZA Public Library Statistics gives a figure of 138,865 e-book downloads for 2011-2012, although some libraries note that they have e-books available but have not provided download figures, so the true figure is likely higher than this. 


\section{METHODOLOGY}

The project took a primarily quantitative approach, with a survey administered online to representatives of public libraries. The survey questions were written with input from Collaborative Services and Public Lending Right staff from the National Library, of New Zealand, in order to ensure that the results would provide useful data for NLNZ's E-book initiative. The survey was created using the Qualtrics online survey platform, and emailed to New Zealand public library managers. Te Puna Services, part of Collaborative Services at the National Library, provided the list of 67 library managers (LIANZA counted 68 public library systems in New Zealand in their 2011/2012 statistics, so the contact list provided may not have been quite comprehensive).

The invitation to the survey was emailed to the managers along with the information sheet provided in Appendix A. The recipients were asked to complete the survey or to delegate it to another appropriate staff member. The survey link was generated by Qualtrics, and was unique to each invitation in order to avoid the problem of accidentally receiving more than one response from a single library system. Any data linking survey responses to invitees or their email addresses was discarded by Qualtrics upon completion of the survey, ensuring that responses were anonymous. A copy of the survey questions has been provided in Appendix B.

The Qualtrics software enabled me to send reminder emails to those managers who had not completed the survey. A first reminder was sent one week after the original invitation, and a final reminder one week after that.

Unfortunately, some respondents who started the survey and attempted to return to it later were blocked from completing it, with Qualtrics informing them they had already submitted it. Two people contacted me about this problem after being sent the reminder that only went to email addresses that still had open survey links, suggesting a this was due to a problem with Qualtric's software. The two managers were given new links, but because submitted surveys had no identifying information associated, I was unable to locate their initial incomplete responses with certainty. Based on comparing the complete and incomplete responses within the library size category of each of the two libraries that requested new links, however, I am reasonably confident that their initial responses were among the incomplete responses I discarded from analysis, so they were most likely not represented twice in the results. 


\section{RESULTS}

The survey invitation list provided by Te Puna contained managers of 67 libraries, one fewer than the 68 public libraries included in LIANZA's 2011-2012 Public Library statistics. Forty-one responses were received, but seven of these had been submitted after only the first few questions had been answered and so were discarded from the analysis. The overall valid response rate of invited participants was therefore $34 / 67$, or $50.8 \%$. This is a reasonable response rate for an email survey, but given that the population of possible respondents was less than seventy, a fifty percent response rate did not generally provide enough data to discover statistically valid correlations. Therefore the following results must be taken as providing descriptive insight only.

\section{Library size}

I have used LIANZA's library size groupings in this survey, although I have further divided large libraries by adding a category for greater than 100,000 population served.

Throughout the results, the following labels are applied:

Level 3: Libraries serving population of less than 30,000

Level 2: Libraries serving population of $30,000-49,999$

Level 1(L): Libraries serving population of 50,000-99,999

Level 1(XL): Libraries serving population of 100,000 or more.

The response rate differed by library system size. The total number of New Zealand public library systems in each size category is taken from LIANZA's 2011-2012 Public Library

Statistics. According to LIANZA's statistics, there are seven public library systems serving a population greater than 100,000. Even after discarding an incomplete response from a respondent who had selected this size (likely to be from one of the two libraries that requested a new survey link), eight respondents to the survey placed their library in this category. I am unsure whether this was due to a mistake from a respondent, an error in LIANZA's statistics, or because LIANZA and the anomalous library use a different source or method to calculate their population. This anomaly gives a response rate for this category greater than $100 \%$.

The response rate decreases with library size, with 100\% of large and extra-large libraries responding compared to only $36 \%$ of small libraries (see Table 1 ). 


\begin{tabular}{|l|l|l|l|}
\hline Library size & $\begin{array}{l}\text { Total in NZ } \\
(\text { according to } \\
\text { LIANZA) }\end{array}$ & $\begin{array}{l}\text { Survey } \\
\text { responses }\end{array}$ & $\begin{array}{l}\text { Response rate } \\
(\%)\end{array}$ \\
\hline $\begin{array}{l}\text { L1- Extra-large } \\
(>100,000)\end{array}$ & 7 & 8 & 114.3 \\
\hline $\begin{array}{l}\text { L1- Large } \\
(50,000-99,999)\end{array}$ & 7 & 7 & 100 \\
\hline $\begin{array}{l}\text { L2 - Medium } \\
(30,000-49,000)\end{array}$ & 16 & 9 & 56.3 \\
\hline $\begin{array}{l}\text { L3 - Small } \\
(<30,000)\end{array}$ & 28 & 10 & 35.7 \\
\hline
\end{tabular}

Table 1: Response rate by library size

The results of the survey were cross-tabulated by library size, but significant low expected frequencies for the null hypothesis (that there is no correlation between library size and other variables) meant that the chi squared tests applied to the data may not be accurate (see Appendix C). Therefore, when results below are shown by library size, the differences may not be statistically significant.

\section{Library e-profiles}

Thirty-two libraries (94.1\%) are currently offering e-books to their users, and the remaining two plan to do so within two years. Twenty-eight libraries (82.4\%) have been offering ebooks to users for at least a year.

Of those already offering e-books, the majority have been doing so for 12-18 months (22 out of 32 libraries, $68.8 \%$ ). Wheelers is used by 10 of the libraries that offer e-books (31.3\%), and Overdrive by 23 (71.9\%). (This adds up to more than $100 \%$ as one library indicated that it uses both.) Of those libraries that use Overdrive, twenty do so via a consortium and three have an individual contract (two of these are extra large libraries and one is a small library).

All four libraries that have started offering e-books within the last year chose Wheelers rather than Overdrive.

In addition to one of the "big two" vendors, two libraries said they use Gale Cengage, and two said they use audiobook provider Bolinda. 
The integration of e-books and other e-resources with the rest of libraries' collection is a growing concern: 19 respondents have an integrated discovery system, or have plans in place to implement one (55.9\%).

Twenty-five (73.5\%) of respondents are members of Aotearoa People's Network Kahuroa, and $30(88.2 \%)$ are members of EPIC.

\section{Spending on e-books and other e-resources}

Unfortunately, the questions on percentage of budget spent on e-resources including ebooks was presented by the survey in such a way as to make it possible to give ambiguous answers. Respondents were asked to indicate the proportion of their total acquisitions budget that is currently spent on e-resources including e-books, and then what proportion of their total acquisitions budget is spent specifically on e-books. They were also asked to provide an estimate on those two proportions in one year's time and five years' time. The question was answered by positioning a slider on a scale. Several repondents positioned the sliders on at least one question to show that they were spending more on e-books than on total e-resources including e-books. In some cases there was only a percentage point or two difference, but in other cases the discrepency was up to eleven percentage points. In these cases I have taken the lower of the two numbers and assigned it to both parts of the question. This is an imperfect solution but it provides the most conservative results.

The mean proportion of current and predicted future Acquisitions spend on total eresources across all responding libraries was calculated, as was the mean proportion spent specifically on e-books. Table 2 and Figures 1 and 2 show that while spending on eresources that are not e-books is predicted to stay relatively steady, spending on e-books is predicted to rise nearly five-fold (although the true factor is probably lower given the input errors on this question). 
Table 2: Mean proportion of Acquisitions budget spent on e-resources (current and estimated future). $s=$ standard deviation

\begin{tabular}{|l|l|l|l|}
\hline Time & Now & $\mathbf{1}$ year & $\mathbf{5}$ years \\
\hline $\begin{array}{l}\text { Total proportion of } \\
\text { Acquistions budget } \\
\text { spent on e-resources } \\
(\%)\end{array}$ & 9.2 & 11.7 & 20 \\
$(\mathrm{~s}=5.3)$ & $(\mathrm{s}=3.5)$ & $(\mathrm{s}=10.4)$ \\
\hline $\begin{array}{l}\text { Non e-book e-resources } \\
(\%)\end{array}$ & 5.9 & 6 & 5.6 \\
$(\mathrm{~s}=5.3)$ & $(\mathrm{s}=5.4)$ & $(\mathrm{s}=6.7)$ \\
\hline E-books(\%) & 3.5 & 5.7 & 14.4 \\
$(\mathrm{~s}=2.6)$ & $(\mathrm{s}=3.5)$ & $\mathrm{s}=(7.2)$ \\
\hline
\end{tabular}

\section{Proportion of Acquisitions spend on e-resources}

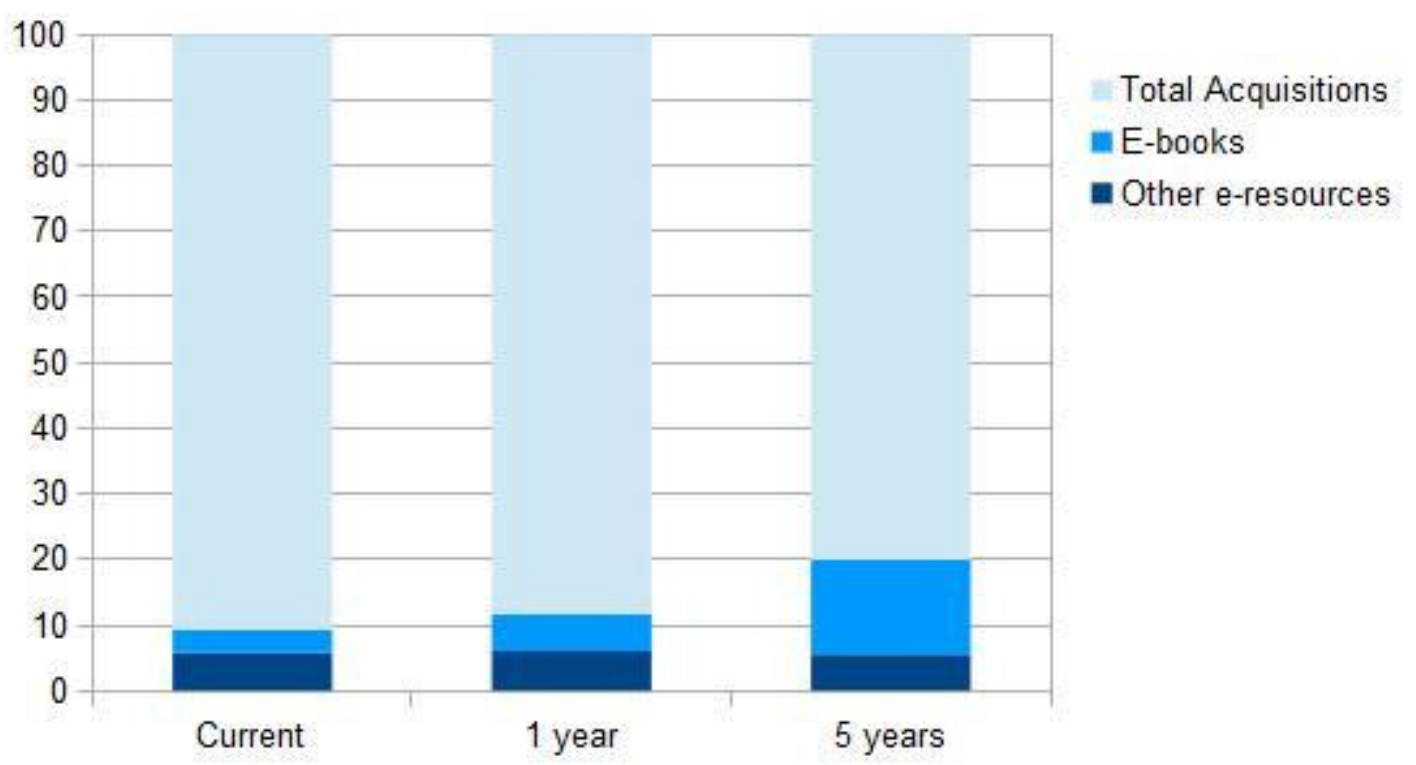

Figure 1: Mean proportion of Acquisitions budget spent on e-resources (current and estimated future) 


\section{Proportion of Acquisitions spend by library size}

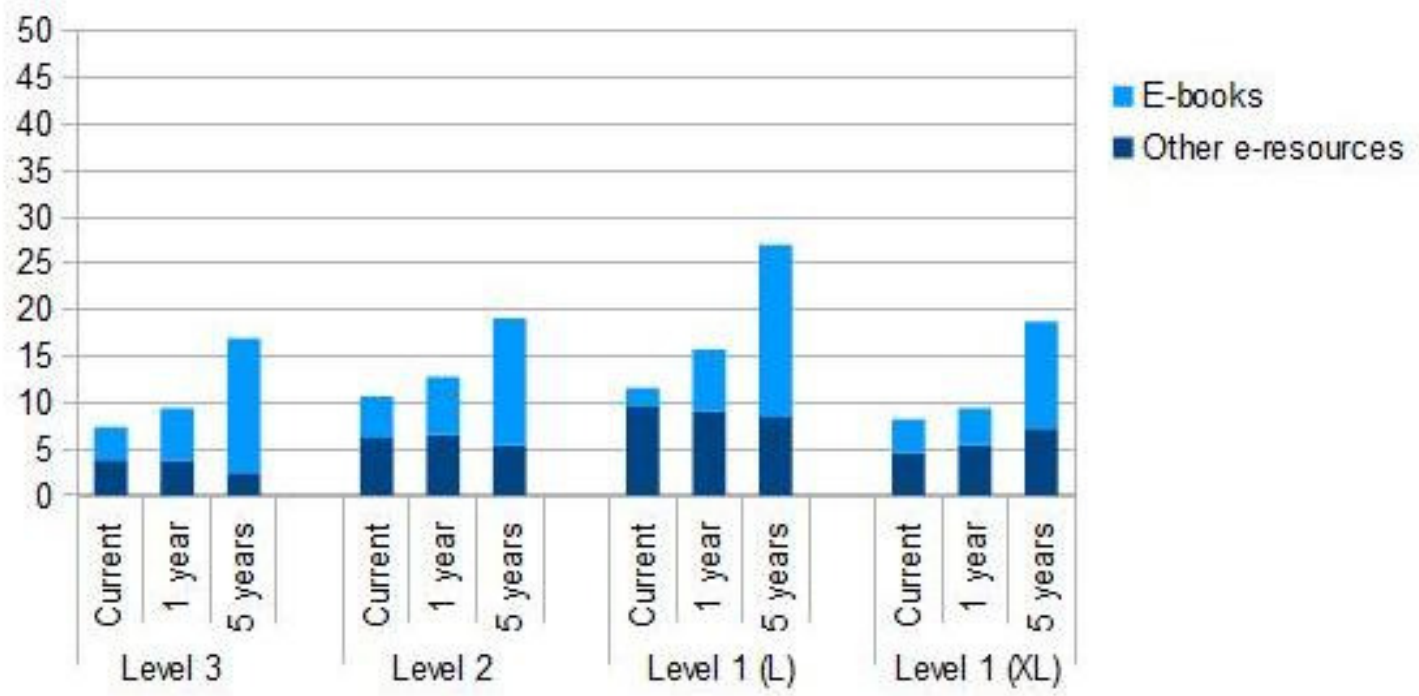

Figure 2: Proportion of Acquisitions budget spent on e-resources, by library size

\section{How are libraries paying for their e-book collections?}

Small libraries are more likely to pay for e-books from their operating expenditure (OPEX) budgets, with seven of the L3 libraries paying for their entire e-book collection from OPEX (70.0\%). Only one L3 library paid for its entire collection from its capital expenditure (CAPEX) budget (10.0\%). Two L3 libraries paid with portions from both (20.0\%).

No medium-sized libraries pay for their e-book collection with a mixture of CAPEX and OPEX, but are fairly evenly split on whether they pay from CAPEX or OPEX - four L2 libraries pay from CAPEX and five from OPEX (44.4\% and 55.6\%, respectively). Large libraries showed a similar distribution, with an even split between purely CAPEX and purely OPEX expenditure.

Extra-large libraries showed an inverse pattern to small libraries, with no libraries paying for e-books entirely from their OPEX budget. Three L1 $(X L)$ libraries (42.9\%) paid from a mixture of both budgets, ranging from $85 \%$ OPEX and $15 \%$ CAPEX to 20\% OPEX and $80 \%$ CAPEX. The remaining four $L 1(X L)$ libraries $(57.1 \%)$ pay entirely from their CAPEX budgets.

All of the libraries that are already offering e-books use one of the "big two" library e-book vendors currently operating in New Zealand. Wheelers sells e-books outright - although they host the content on their own servers, e-books are purchased as a one-off cost rather 
than leased (although a small additional fee is imposed per loan). Overdrive operates a perpetual access model, leasing e-books rather than selling them. Their different licensing models are reflected in the way that libraries pay for their products. Libraries that use Overdrive are more likely to fund their collection from their OPEX budget, while those that use Wheelers tend to fund their collection from their CAPEX budget. One respondent commented:

"Books from Wheelers are regarded as purchases. Books from Overdrive are not, as Overdrive has demonstrated that the books cannot be retained if the service ceases."

Only one responding library uses both Wheelers and Overdrive and they stated that they fund their e-book collection with a 20\% CAPEX/80\% OPEX split. Of the nine libraries that use Wheelers instead of Overdrive, six (66.7\%) fund their e-books entirely from their CAPEX budget, while only two (22.2\%) use only their OPEX budget, and one library (11.1\%) employs a 15\% CAPEX/85\% OPEX split. Of the 22 libraries that use Overdrive instead of Wheelers, twelve fund their collections entirely from their OPEX budget (54.6\%), seven entirely from their CAPEX budget (31.8\%), and three split the cost between both budgets (14.6\%).

Ten libraries (31.3\% of libraries already providing e-books) said that they plan on changing the way that they pay for their e-book collections, but there is not a strong trend in one direction, indicating that libraries are not necessarily converging on a standard way to think about the financial status of their e-book collections (see Table 3). A slight majority (60.0\% versus $40.0 \%$ ) signposted that they would be shifting towards paying more from their OPEX budgets.

It is interesting to note that two respondents said that a move to CAPEX would be desirable because the OPEX budget is more vulnerable to financial decisions from councils, while another anticipated a shift to OPEX based on the likelihood of a national subscription model - this may be a tension that needs to be addressed in the potential development of any such model. One respondent from a library that funds all of its e-books from OPEX and anticipates continuing to do so in future also addressed this point:

"The e-book model of purchasing access is a problem for libraries when they are funded for materials in general via a capital budget. This cannot be used for subscriptions or purchased access so costs for e-books have to be taken from operational budgets. It is very difficult to increase operational budgets but in general less of a problem for OPEX so we have a problem of high demand for material that we have major problems in funding." 
Table 3: Libraries that anticipate changing the balance of CAPEX and OPEX funds that e-books are acquired from

\begin{tabular}{|c|c|c|c|}
\hline Current split & $\begin{array}{l}\text { Anticipated } \\
\text { split in } 5 \\
\text { years }\end{array}$ & $\begin{array}{l}\text { Direction } \\
\text { of change }\end{array}$ & Reason \\
\hline $100 \%$ CAPEX & $\begin{array}{l}50 \% \text { CAPEX } \\
50 \% \text { OPEX }\end{array}$ & OPEX & $\begin{array}{l}\text { Will better reflect that } 50 \% \text { is subscription and } 50 \% \text { is } \\
\text { ownership. However, withdrawal from consortia also } \\
\text { means loss of existing e-books, so may need to } \\
\text { review, or apply a unique depreciation formula. }\end{array}$ \\
\hline $100 \%$ CAPEX & $100 \%$ OPEX & OPEX & $\begin{array}{l}\text { Council is currently looking at collection value } \\
\text { implications around e-books for audit and have } \\
\text { indicated e-books may be OPEX in future. }\end{array}$ \\
\hline $\begin{array}{l}\text { 75\% CAPEX } \\
25 \% \text { OPEX }\end{array}$ & $\begin{array}{l}90 \% \text { CAPEX } \\
10 \% \text { OPEX }\end{array}$ & CAPEX & $\begin{array}{l}\text { Currently subscription costs for e-books come from } \\
\text { OPEX; hopefully subscription costs will diminish } \\
\text { allowing additional CAPEX spend. }\end{array}$ \\
\hline $100 \%$ OPEX & $100 \%$ CAPEX & CAPEX & $\begin{array}{l}\text { Physical books are funded from CAPEX and manager } \\
\text { wants e-books to be funded from same. }\end{array}$ \\
\hline $100 \%$ OPEX & $100 \%$ CAPEX & CAPEX & $\begin{array}{l}\text { Hope to persuade auditors/accountants to transition } \\
\text { some Acquisitions funds from OPEX to CAPEX to } \\
\text { fund growth in e-resources as in some cases we see } \\
\text { them as a direct replacement for physical content and } \\
\text { if correctly licensed we feel they are an asset - the } \\
\text { accountants so far disagree! If this doesn't work we } \\
\text { will have to raise new OPEX revenue sources which } \\
\text { seems unlikely in current financial climate. }\end{array}$ \\
\hline $100 \%$ OPEX & $\begin{array}{l}50 \% \text { CAPEX } \\
50 \% \text { OPEX }\end{array}$ & CAPEX & $\begin{array}{l}\text { Move to more of an ownership-based model, as } \\
\text { opposed to an access-based model. Desirable to } \\
\text { have some in CAPEX as overloading OPEX for } \\
\text { collection resources introduces vulnerability when } \\
\text { council is looking to reduce costs. }\end{array}$ \\
\hline $\begin{array}{l}33 \% \text { CAPEX } \\
67 \% \text { OPEX }\end{array}$ & $100 \%$ OPEX & OPEX & As financial standards are set across the industry. \\
\hline $\begin{array}{l}80 \% \text { CAPEX } \\
20 \% \text { OPEX }\end{array}$ & $\begin{array}{l}50 \% \text { CAPEX } \\
50 \% \text { OPEX }\end{array}$ & OPEX & $\begin{array}{l}\text { Business models being offered by suppliers are } \\
\text { changing. }\end{array}$ \\
\hline $100 \%$ CAPEX & $\begin{array}{l}50 \% \text { CAPEX } \\
50 \% \text { OPEX }\end{array}$ & OPEX & $\begin{array}{l}\text { Expect there to be a national consortium for e-book } \\
\text { purchasing via subscription model. }\end{array}$ \\
\hline 100\% CAPEX & $\begin{array}{l}40 \% \text { CAPEX } \\
60 \% \text { OPEX }\end{array}$ & OPEX & $\begin{array}{l}\text { Books from Wheelers are regarded as purchases. } \\
\text { Books from Overdrive are not, as Overdrive has } \\
\text { demonstrated that the books cannot be retained if the } \\
\text { service ceases. }\end{array}$ \\
\hline
\end{tabular}

Of the two libraries that do not yet provide e-books, one indicated that they plan on a 50/50 split; the other did not provide a valid response to this question.

2 NB: Original comment said "transition some Acquisitions funds from CAPEX to OPEX", but given the rest of the comment and the figures provided for the questions on current and anticipated CAPEX/OPEX fund, I have taken the liberty of assuming this was an error. 


\section{New Zealand e-books}

The survey asked what proportion of library e-book collections would consist of New Zealand titles if there were no barriers to acquisition/provision of access. Answers ranged from two to fifty percent, with a mean of $20.9 \%(s=12.1)$. One respondent commented that they would find a pay-per-use model "amazing" as a way of providing access to the "long tail" of New Zealand publishing.

\section{Evaluating licensing models}

Seven potential models of e-book licensing were presented to respondents for evaluation. These models are based on models currently in use in the public library environment and the tertiary library environment, and other proposed models from the literature and press.

The models were:

- Perpetual access

- License that expires after a set number of loans

- License that expires after a set time period

- Subscription packages (ie. the library does not select individual titles, but gets a package based on topic area, publisher, etc)

- Pay-per-use

- Combination of perpetual access with pay-per-use (ie. lower initial payment for title, but small fee charged for each use)

- Rent-to-own

Respondents were asked to rate each of these models as "Unacceptable," "Would consider if no other options were available," "Acceptable," "Highly acceptable" or "Optimal" (see Figure 3). 


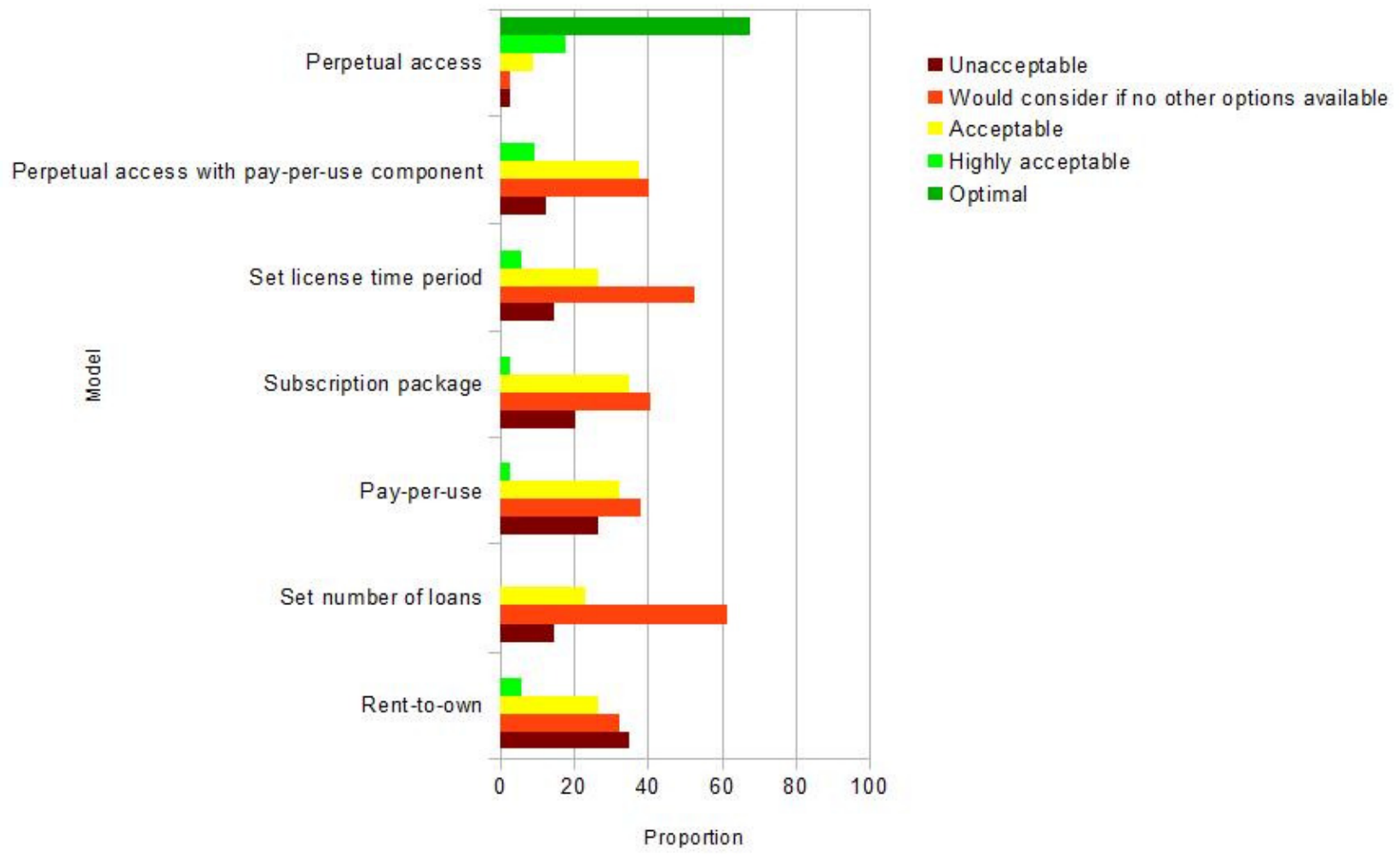

Figure 3: Comparison of public libraries' acceptance of possible e-book licensing models

Of the suggested models, Perpetual Access was the only one considered Optimal by any library at all, and was considered so by 23 libraries (67.7\%). A total of 29 libraries found this model either Optimal or Highly Acceptable (85.3\%). It was the only model that over fifty percent of respondents considered acceptable or higher (ie. assigning a rating of Acceptable, Highly Acceptable or Optimal). The model considered acceptable by the next highest number of respondents was the model that would combine perpetual access with a pay-per-use system (ie. lower initial payment for individual titles, but small fee charged for each use). Fifteen of the 32 of respondents who rated this option (two respondents did not assign it any rating) considered this model acceptable or higher (46.9\%), although only only three libraries found it Highly Acceptable (9.4\%) and none considered it Optimal. All other proposed models were only considered acceptable or higher by 11-13 of respondents (32.4-38.2\%), with the exception of the model based on a set number of loans, which was only considered acceptable by eight libraries (23.5\%), with none of those finding it Highly Acceptable or Optimal. 
A weighted score for each model was calculated by assigning a multiplier to each response option:

- Unacceptable $=0$

- Would consider if no other options available $=1$

- Acceptable $=2$

- Highly acceptable $=3$

- Optimal $=4$

The weighted responses were summed and divided by the sample size of 34 (except for the Perpetual access with pay-per-use model, to which only 32 respondents chose to assign a rating). The maximum possible score is therefore 4.0 (all respondents would consider this option Optimal), and the minimum possible score is 0 (all respondents would consider this option Unacceptable). See Table 4.

Table 4: Ratings for proposed license models

\begin{tabular}{|l|l|l|l|l|}
\hline Model & $\begin{array}{l}\text { Weighted } \\
\text { score (out of } \\
\mathbf{4 . 0}\end{array}$ & $\begin{array}{l}\text { Unacceptable } \\
(\%)\end{array}$ & $\begin{array}{l}\text { Acceptable or } \\
\text { higher (\%) }\end{array}$ & $\begin{array}{l}\text { Highly Acceptable or Optimal } \\
(\%)\end{array}$ \\
\hline $\begin{array}{l}\text { Perpetual } \\
\text { access }\end{array}$ & 3.44 & 2.9 & 94.1 & 85.3 \\
\hline $\begin{array}{l}\text { Perpetual } \\
\text { access with } \\
\text { pay-per-use }\end{array}$ & 1.44 & 12.5 & 46.8 & 9.4 \\
\hline $\begin{array}{l}\text { Set time } \\
\text { period }\end{array}$ & 1.24 & 14.7 & 32.4 & 5.9 \\
\hline $\begin{array}{l}\text { Subscription } \\
\text { package }\end{array}$ & 1.21 & 20.6 & 38.2 & 2.9 \\
\hline Pay-per-use & 1.12 & 26.5 & 35.3 & 2.9 \\
\hline $\begin{array}{l}\text { Set number of } \\
\text { loans }\end{array}$ & 1.08 & 14.7 & 23.5 & 0 \\
\hline Rent-to-own & 1.03 & 35.3 & 32.4 & 5.9 \\
\hline
\end{tabular}

Comparing the weighted scores to the percentage of libraries that would find a given option unacceptable, we can see that while libraries are generally quite unenthusiastic about licenses that expire after a set number of loans, there are fewer libraries that would refuse to consider that model than would refuse to consider subscription packages, payper-use or rent-to-own models. This may be because it is one of the more established 
models in public library e-book lending, and libraries have already learnt to be pragmatic in accepting this license condition as a means to provide access to their users -21 libraries $(61.8 \%)$ said that they would accept this model if no other options were available, which may well be the situation they find themselves in now. The models that are most likely to be dismissed out of hand are all models that are currently more common in the tertiary library environment.

The weighted ratings for each library size are provided, with the caveat that the sample size is too small for differences to be statistically significant (see Figure 4).

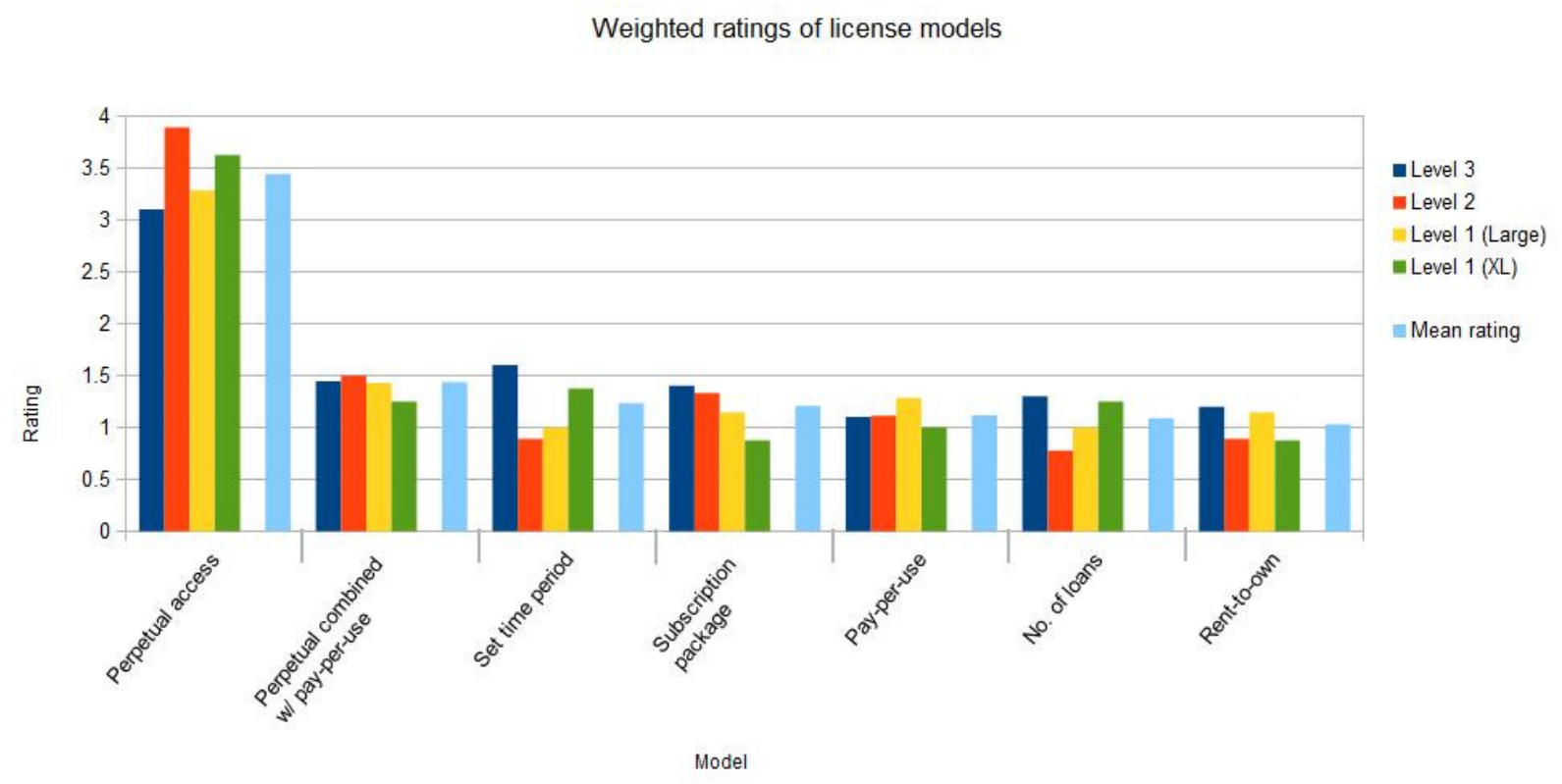

Figure 4: Weighted ratings for license models (by library size)

Respondents were provided the opportunity to give free-text comments on license models. The predominant theme was that libraries would like flexible license options, with different options for different types of books (see the Discussion section of this paper).

\section{Loan-based expiration vs. time-based expiration of licenses}

Publishers have advocated for expirations on licenses in order to artificially create the need to repurchase titles, arguing that the natural process of wear and tear creates this need for print material. The main two options they have been exploring for e-books that expire are limited loan, where books can only be lent a set number of times before the licence needs to be re-purchased, and limited time, where libraries purchase a licence for a set amount of time. The survey asked which of these options libraries preferred, and 
what would be the minimum number of loans or time period that would be acceptable.

Besen \& Kirby (2012) hypothesise that larger libraries might prefer time as the condition for expiration, as they would be more likely to loan a title more often in a set time period than a smaller library; while a smaller library might prefer number of loans, as it would take longer for their titles to reach the limit. However, it can be seen that all libraries except Level 2 prefer a limit based on number of loans (see Figure 5). This largely contradicts the results seen when libraries were asked to rate various models, as set time period was higher ranked. However, in each case except extra large libraries, there was only one vote difference whe asked to choose between expiration based on time and based on loans. This probably serves to highlight that the significance of these results is not robust due to the small sample size (it was also at this point that one respondent from a small library left the survey, and did not complete this set of questions on preferences for license expiry options, or the final set on license attributes).

\section{Preference between limited loan and fixed time period licenses}

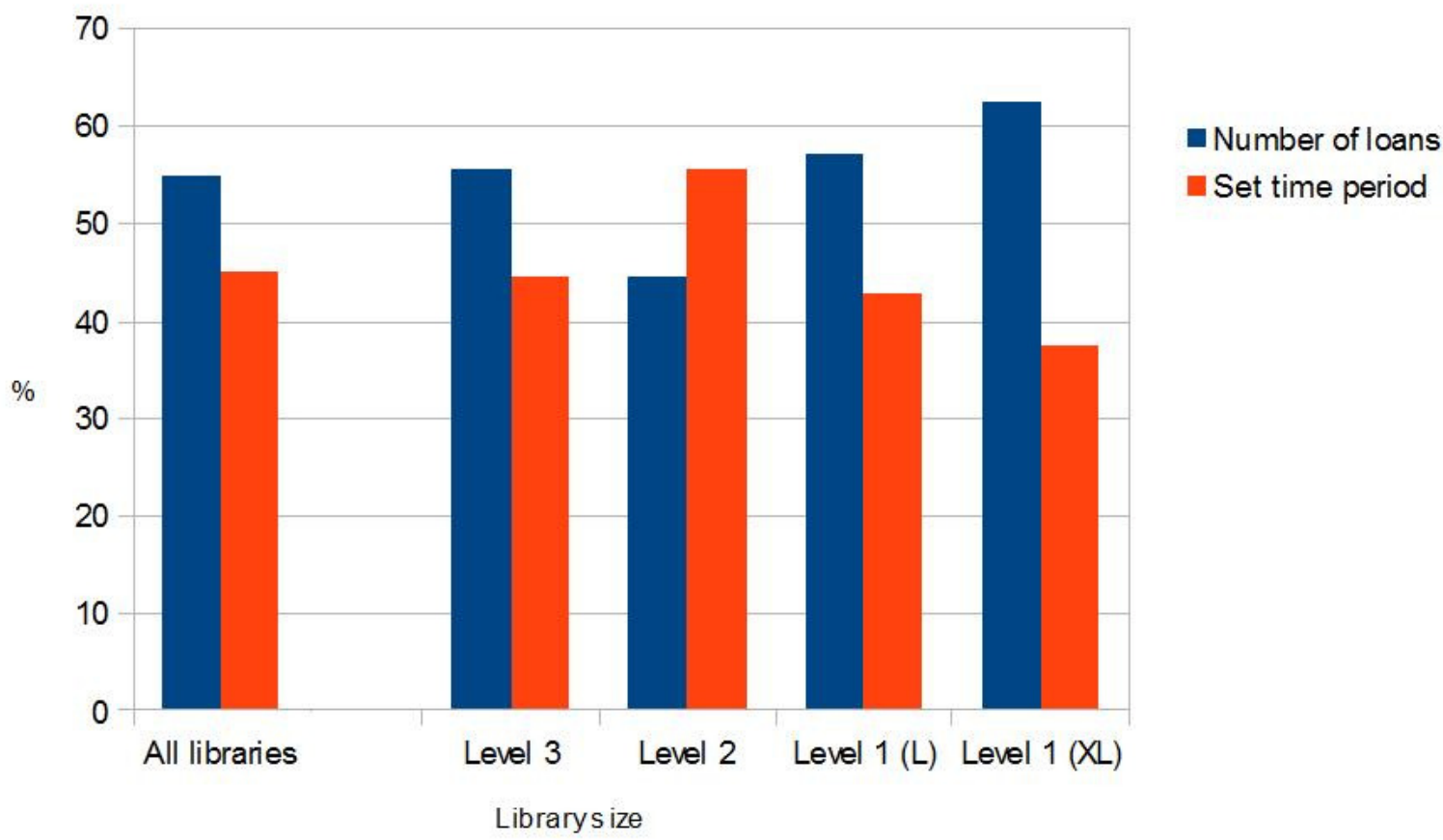

Figure 5: Preference for loan- $v$ s time-based license expiration condition 
Respondents who didn't indicate that limited loans or set time periods were unacceptable were asked to indicate the minimum number of loans or minimum time period before a license expired that they would accept. Table 5 and Figure 6 shows the lowest and highest value selected by any library in each size group, and the mean value in each group. The range and mean were also calculated for the whole group (note: the calculations for mean values exclude the libraries that consider a limit of that type unacceptable).

Table 5: Preferred minimum loan number or time period for license expiration

\begin{tabular}{|l|l|l|l|l|l|}
\hline Size & 3 & 2 & 1 (Large) & $1(\mathrm{XL})$ & All \\
\hline $\begin{array}{l}\text { Proportion of total sample } \\
\text { who find a loan limit } \\
\text { acceptable }\end{array}$ & $70.0 \%$ & $77.80 \%$ & $100.0 \%$ & $87.5 \%$ & $85.30 \%$ \\
\hline $\begin{array}{l}\text { Lowest minimum loans } \\
\text { considered acceptable }\end{array}$ & 20 & 40 & 25 & 25 & 20 \\
\hline $\begin{array}{l}\text { Mean minimum loans } \\
\text { considered acceptable }\end{array}$ & 29.3 & 58.9 & 42.1 & 35.9 & $\begin{array}{l}41.5 \\
(\mathrm{~s}=17.9)\end{array}$ \\
\hline $\begin{array}{l}\text { Highest minimum loans } \\
\text { considered acceptable }\end{array}$ & 50 & 81 & 61 & 80 & 81 \\
\hline $\begin{array}{l}\text { Proportion of total sample } \\
\text { who find a time limit } \\
\text { acceptable }\end{array}$ & $80.0 \%$ & $55.60 \%$ & $85.70 \%$ & $75.0 \%$ & $85.30 \%$ \\
\hline $\begin{array}{l}\text { Shortest minimum time } \\
\text { considered acceptable } \\
\text { (months) }\end{array}$ & 23.5 & 12 & 24.2 & 11.4 & 11.4 \\
\hline $\begin{array}{l}\text { Mean minimum time } \\
\text { considered acceptable } \\
\text { (months) }\end{array}$ & 34.5 & 34 & 34.2 & 25.9 & $\begin{array}{l}32.3 \\
(\mathrm{~s}=14.8)\end{array}$ \\
\hline $\begin{array}{l}\text { Longest minimum time } \\
\text { considered acceptable } \\
\text { (months) }\end{array}$ & 60 & 60 & 36.3 & 48 & 60 \\
\hline
\end{tabular}



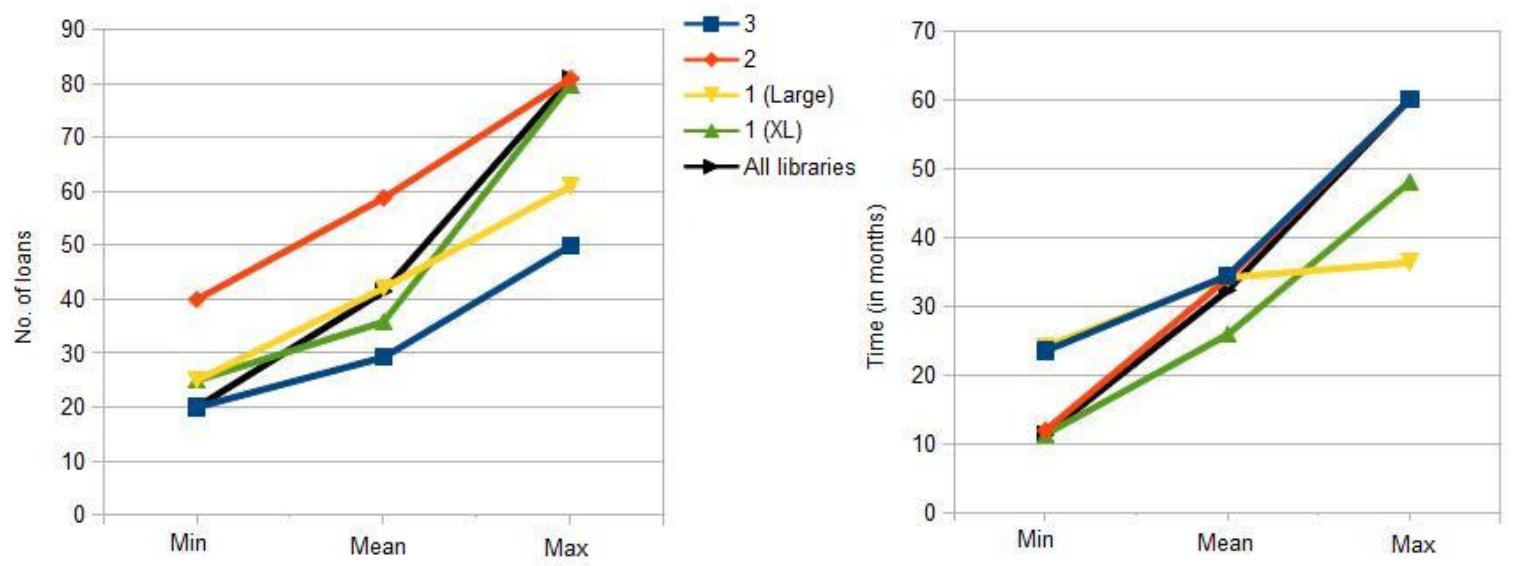

Figure 6: Lowest, highest and mean preferred minimum conditions for license expiry

The mean time limit on licenses considered acceptable was 34 months for all library sizes except $L 1(X L)$, which supports the hypothesis that the largest libraries would get relatively more value from time-limited licenses. However, $L 1(X L)$ libraries also had the secondlowest mean acceptable minimum number of loans. Taken together, this might indicate that larger acquisitions budgets make Extra Large libraries less wary of licence limitations than smaller libraries. Smaller libraries would be accepting of the fewest minimum loans per license, and wanted the longest time limits, although by a very small margin. This is consistent with Besen \& Kirby (2012) but is not strong evidence, especially with regards to time-limited loans.

\section{License attributes}

The final set of questions asked respondents to evaluate a set of 15 attributes that e-book models could include. The attributes were:

- Access does not expire after set time period

- Access does not expire after set number of loans

- No embargo period for the library e-book edition compared to the commercially available e-book

- Provision of preservation files of specific titles for the library to own on their own server or cloud storage

- Integration with library's ILS

- Integration with library's acquisition workflows for print materials

- Ability to charge user fees for e-books 
- Offline access for borrowers during the loan period

- Simultaneous access for multiple users

- Access to titles from independent publishers and self-published authors

- Access to New Zealand titles

- Compatibility with all devices

- Links from discovery system for users to purchase titles

- Triggers for purchases of additional copies based on user demand (eg. hold requests)

- Integration of titles supplied by different vendors through one discovery interface

As with the question about license models, a weighted score for each attribute was calculated by assigning a multiplier to each response option:

- Not required $=0$

- Neutral/No opinion $=1$

- Nice to have, but not necessary $=2$

- Would make license more attractive $=3$

- Necessary $=4$

The weighted responses were summed and divided by the total number of respondents who ranked a given attribute. The maximum possible score is therefore 4.0 (all respondents would consider this attribute Necessary), and the minimum possible score is 0 (no respondents would want this option). Table 6 shows how respondents ranked these attributes.

The most important attributes were compatibility with all devices (rating $=3.64 / 4)$, and New Zealand content (3.45). System integration was also considered important: the next two highest rated attributes were integration of e-books with library ILS (3.42), and a single platform for accessing content even if content is provided by multiple vendors (3.15). The final two attributes ranking above 3.0 reiterate that libraries really would prefer not to deal with licenses that expire after a set time period or number of loans.

The two attributes that received the lowest weighted rating and the fewest respondents considering them necessary are both the options that allow libraries to generate revenue from e-book lending:the ability to charge fees (1.55), and links for users to purchase titles (1.85). Respondents were also not especially worried about automated triggers to purchase copies based on demand (2.50), or the provision of preservation copies (2.61). 
One respondent raised the issue again here that it would be good to be able to select different license attributes for different titles:

"Ability to vary the conditions for different collections - so that we can align ebook with p-book in terms of our collection management. For example we may want to retain forever an item that we would want for our heritage collection, but would want to discard from the collection a popular fiction item after two years and lower-demand non-fiction item after five years or perhaps on the basis of turnover, such as $x$ number of issues per year. Essentially we might want to continue to operate our collection policy/collection practices regardless of the format of the collection items - p-book or e-book."

Table 6: Ratings of e-book license attributes

\begin{tabular}{|c|c|c|c|c|}
\hline Attribute & $\begin{array}{l}\text { Weighted score } \\
\text { (out of } 4.0 \text { ) }\end{array}$ & $\begin{array}{l}\text { Not required or } \\
\text { no opinion (\%) }\end{array}$ & $\begin{array}{l}\text { Attractive or } \\
\text { Necessary (\%) }\end{array}$ & $\begin{array}{l}\text { Necessary } \\
(\%)\end{array}$ \\
\hline $\begin{array}{l}\text { Compatibility with all } \\
\text { devices }\end{array}$ & 3.64 & 3.03 & 96.97 & 69.70 \\
\hline $\begin{array}{l}\text { Access to New Zealand } \\
\text { titles }\end{array}$ & 3.45 & 0 & 90.91 & 54.55 \\
\hline Integration with ILS & 3.42 & 0 & 90.91 & 51.52 \\
\hline $\begin{array}{l}\text { Integration of titles supplied } \\
\text { by different vendors }\end{array}$ & 3.15 & 9.09 & 81.82 & 42.42 \\
\hline $\begin{array}{l}\text { Does not expire after set } \\
\text { time period }\end{array}$ & 3.12 & 6.06 & 90.91 & 27.27 \\
\hline $\begin{array}{l}\text { Does not expire after set } \\
\text { number of loans }\end{array}$ & 3.09 & 3.03 & 90.91 & 21.21 \\
\hline $\begin{array}{l}\text { Simultaneous access for } \\
\text { multiple users }\end{array}$ & 2.91 & 3.03 & 78.79 & 15.15 \\
\hline $\begin{array}{l}\text { Access to titles from } \\
\text { independent publishers and } \\
\text { self-published authors }\end{array}$ & 2.91 & 3.03 & 78.79 & 15.15 \\
\hline $\begin{array}{l}\text { Integration with acquisition } \\
\text { workflows for print } \\
\text { materials }\end{array}$ & 2.85 & 12.12 & 72.73 & 27.27 \\
\hline No embargo period & 2.82 & 12.12 & 75.76 & 24.24 \\
\hline $\begin{array}{l}\text { Offline access for } \\
\text { borrowers during loan }\end{array}$ & 2.81 & 18.75 & 65.63 & 40.63 \\
\hline $\begin{array}{l}\text { Provision of preservation } \\
\text { files when required }\end{array}$ & 2.61 & 6.06 & 60.61 & 6.06 \\
\hline $\begin{array}{l}\text { Triggers for purchases of } \\
\text { additional copies }\end{array}$ & 2.50 & 12.50 & 56.25 & 9.38 \\
\hline $\begin{array}{l}\text { Links for users to purchase } \\
\text { titles }\end{array}$ & 1.85 & 27.27 & 21.21 & 3.03 \\
\hline Ability to charge user fees & 1.55 & 51.52 & 30.30 & 6.06 \\
\hline
\end{tabular}




\section{Comments}

Respondents were given the opportunity to provide free-text comments about e-books and licensing: they were asked which one innovation would make e-book lending most successful for their users, and also if they had any more genral comments about e-books, licensing and the survey. Comments not already reproduced elsewhere in this results section will be considered in the Discussion section of this paper.

\section{DISCUSSION}

Public library e-lending has become widely established in New Zealand: based on LIANZA statistics and the more recent (but lower response rate) findings of this survey, the percentage of public library systems offering e-books is between $70 \%$ and $94 \%$, with more library systems planning to start offering e-books in the near future. However, libraries are very constrained in their ability to build e-book collections compared to print book collections.

Libraries are currently spending an average of nearly ten percent of their acquisitions budgets on e-resources. Currently less than half of spending on e-resources goes towards e-books, but libraries anticipate that balance will shift: spending on non e-book eresources is predicted to hold steady at 5-6 percent of acquisitions budgets over the next five years, but spending on e-books is set to soar to nearly 15 percent of libaries' total acquisitions spend. This has implications for how libraries budget for their core collections, as licensed materials such as e-books tend to come from OPEX spending, which is more vulnerable to external influences (ie. council-imposed cuts and restrictions at times of budget pressure). This is an issue that may need to be addressed by any attempt at a national-level project for better library e-book access.

The survey showed that there is an appetite for more New Zealand material in New Zealand public library e-book collections, with one respondent suggesting a pay-per-use model providing access to the "long tail" of New Zealand publishing. There is potential for NLNZ to work in partnership with New Zealand publishers on such a scheme, although costs of digitising back-list titles must be balanced with potential revenue.

It is hardly surprising that perpetual access was the most preferred model for e-book licenses by a huge margin $-67.7 \%$ of respondents considered this the optimal model, and no other proposed model was considered optimal by any library. Perpetual access combined with a small fee per loan (ie. Wheelers' current model) was the next most 
preferred option, but less than half of the libaries surveyed considered it acceptable. The "HarperCollins" model of licenses that expire after a set number of loans was considered acceptable by the lowest number of libraries, with less than a quarter of libraries considering it acceptable. However, libraries seem to concede that they may need to work with this model as it is popular with publishers - they may not like it, but few libraries rule it completely unacceptable, with over sixty percent saying that they are prepared to consider it when no other options are available. For this reason, it achieves a higher weighted rating than models that are reasonably well established in the tertiary library market (eg. subscription or pay-per-use). The low ratings for these models may be because tertiary libraries users are more likely to require access to low-use titles that are of high value to their specific information needs, while public libraries are more concerned with popular titles.

Free-text comments regarding possible models indicate that libraries are hopeful that ebooks could be treated quite differently to the traditional way in which print collections are acquired, and would like to see flexibility, with different licences offered for different types of material - and preferably at different prices reflecting the benefits and limitations of each model.

"Different types of content might need different models. A popular intial title might work well with some on a licence that expires, while some are held in perpetuity. [Or] a model where the library pays more for unlimitied simultaneous use while the item is popular and then it drops to single use later."

"Close to what is suggested above as subscription package, but is based upon an option where the library customer has access to the full list of a publisher's catalogue and we simply pay for what our customers have used - a patrondriven acquistion process."

"A huge amount depends on price. Set-use expiry (eg. Harper Collins) is unacceptable when set arbitrarily and for the full retail and with DRM-locked content. For a lesser fee reflecting the use, the model becomes more acceptable. Same for many of the other options. But hard to see why libraries should accept less than what we have. We buy it, we own it in the physical realm and the only limitations are based on law and copyright. Now we're told we must accept we can only buy some (not all - due to regional licensing or flatout refusal to trade with libraries) at the whim of the publisher and with multiple additional restrictions (eg only print five pages, no printing at all, DRM making the ebook extremely difficult to use, etc). This is the public's money we are spending here to build a collection for the use of the public. We need to negotiate a deal that is fair to all - and so far what has been offered is fairest to the publishers and their selected vendors (eg. Overdrive) and not to our members who are being denied access to increasing amounts of content." 
"Subscription package based on fixed number of titles, that allows underutilised titles to be exchanged for new titles as part of a collection management process."

Across several sections of the survey, libraries expressed a slight preference for timebased expiration over loan based expiration. Time limited licenses may be easier to budget for, and there is less wastage from people who borrow e-books but don't end up reading them (although if a title is in demand they will waste some of the time on the license). Respondents would prefer longer licenses than are typically on offer now - the mean minimum loans preferred was 41.5 , and the mean minimum time limit was 32.3 months. Of the Big Six publishers, Macmillan currently comes closest, with licenses that expire after the earlier of two years or 52 loans (although their trial only includes titles from its Minotaur imprint). There was not a strong difference of preference for time- or loan-based expiration between library systems of different size.

The most important license attributes were primarily related to ease of use - compatibility with all devices and system integration (with ILS and with content from multiple vendors). The other important attribute was access to New Zealand content (probably because this is comparatively lacking at present). The least important aspects were provision of preservation copies (suggesting that libraries are growing more comfortable with the idea of not owning their e-book collections), triggers for purchases of additional copies for high demand titles, links for users to purchase titles, and the ability to charge user fees (it is interesting that only six percent considered the ability to charge fees necessary, implying that not many libraries are intending to use e-books as a source of revenue generation in the way that overdue fees and bestseller charges on print books are used by some library systems).

The concerns over ease of use and integration were reiterated in the free-text comments provided in response to the questions, "Are there any e-book licensing conditions not listed above that you think would be attractive for your library?" and "What would be the one innovation that would make e-book lending in your library the biggest success for your customers?":

"It all comes down to ease of use - the current arrangements are not very good in this regard - and value for money."

"A single search [interface]"

"Discoverability through ILS and seamless downloads - one stop shop. This is a new development for our ILS that will facilitate this through APIs" 
"Seamless interaction between catalogue and e-book provider making it really easy to download titles"

"Integration of titles supplied by different vendors through one discovery interface"

"Easy integration into ILS"

"Integration of all vendors into one platform"

"If the platforms offered were less clunky and easier to use"

"Common platforms and business models"

The importance of device compatibility was mainly expressed in comments about Kindle, which is not currently supported by library lending platforms in New Zealand:

"Having Kindles work with libraries"

"Ability to use Kindle devices, as the Kindle is by far the best e-reader device on the market."

"Able to download Overdrive onto the Kindle"

"File format standard"

Also on the subject of ease of use, DRM is seen as a problem when it makes borrowing more difficult and requires staff assistance for users:

"DRM is a constant issue for users, and not in a good way. As barriers to uptake go it costs us a lot of staff time working borrowers through setting up access."

"Drop the DRM, or make it invisible. A single interface for all ebooks regardless of vendor (OK, so that's two!)"

"Removal of DRM"

On a similar note, one respondent said that better "customer support" would make e-book lending a bigger success. 
Three respondents picked simultaneous access as the most important aspect to improve:

"Simultaneous access for multiple users, so that our users do not have to place holds when they find a title they want to borrow."

"Simultaneous loans. It's a nonsense that an electronic file can only be downloaded / accessed by one person at a time "

"Multiple copies of the same e-book would be favoured by our customers"

The other major cluster of responses was around addressing the limitations of e-book collections and acquisitions compared to print books:

"E-books should be treated like any other books"

"Abolishing territorial rights so customers can have access to any title, popular bestsellers and older backlist, as soon as it is available in any format/country."

"More choice of titles"

"That the online browsing of e-books could replicate the same browsing experience that people get in the real, physical world. If customers can then get access to the same range of materials in e-book as they can in p-book and all of this then becomes available on all mobile devices then this would make the whole library e-book experience a bigger success than currently. / Having apps that links from online bookstores to local libraries where an ebook can be dowloaded for borrowing, and the reverse, where a customer can buy something that they have enjoyed reading is a good experience for customers."

\section{LIMITATIONS/SUGGESTIONS FOR FURTHER RESEARCH}

It must be stressed again that the results of this survey were generally not statistically significant due to the small total population that the sample could be drawn from (ie. Number of public library systems in New Zealand). This barrier to reaching statistically significant results was compounded by the low response rate from small libraries. Small libraries are likely to have fewer resources at their disposal to build e-book collections for their users, and are likely to benefit more from a collaborative approach, so it is a shame that they are under-represented in this study.

Libraries are only one of the stakeholders in the current discussion around library e-book lending. If the discussion is to achieve successful outcomes then it must include all affected parties including publishers, authors, distributors and users. However, surveying multiple stakeholder groups would have made this particular project too large for the scope of an INFO 580 project; it must therefore be understood as a piece of work contributing to 
the broader initiative.

It had been hoped during development that this project would include a qualitative phase to further explore the data gathered from the survey. Unfortunately there was not time to carry out this phase as it would have needed to be carried out after analysis of the quantitative results. If such quantitative work would be useful, this could possibly be carried out for NLNZ after the submission of the project for academic requirements. Although a sample size of four is difficult to draw real conclusions from, it is striking that all four libraries that started offering e-books within the last year have chosen local company Wheelers over international leader Overdrive. I would be interested in exploring vendor choices further to determine the reasons behind this apparent trend.

One license attribute that wasn't polled was the portability of titles if libraries should choose to switch e-book platform vendors (although it is probably safe to hypothesise that this would likely be considered a desirable attribute).

The invitation to participate did not explicitly point out that responses were desired from libraries not currently providing e-books as well as those that are. It is possible that this may have skewed the proportion of New Zealand public libraries offering e-books as measured by the survey. Forty-eight of the 68 libraries surveyed for LIANZA's 2011/2012 library statistics $(70.6 \%)$ offered e-books at the time of that survey (including downloadable audiobooks), compared to 32 of the 34 libraries who responded to this survey $(94.1 \%)$.

\section{CONCLUSION}

Libraries will be spending an increasing amount of their Acquisitions budget on e-books in the near future, which will mean a significant shift to licensed rather than purchased collections. Libraries and their funding organisations are grappling with what this may mean for how collections are funded, with several libraries concerned that collection funds increasingly need to come from the more precarious OPEX budget. Perpetual access makes it easier to justify keeping e-book acquisition costs in the CAPEX budget. A national-level platform or purchasing consortium may make a greater number of titles available to libraries at a more reasonable cost, but may not solve these underlying budgetary issues. 
There is an appetite for more New Zealand content in public library e-book collections. This is an issue that is a good fit with NLNZ's advocacy role, and hopefully the dialogue with New Zealand publishers will be a fruitful one. The future for New Zealand's publishing landscape looks likely to include the consolidation of major publishers (which may lead to some New Zealand operations moving offshore), and the increase in self-publishers and small publishing companies. Therefore, provision of New Zealand content may need to include a mechanism for small publishers to sell to libraries.

Perpetual access was definitely the preferred model for e-book licensing. The most popular models tend to be those that allow control over choice of titles and predictability over costs. Libraries recognise that one size doesn't necessarily fit all, and would like to see different license models for different types of content, and would be prepared to spend more for more flexible license options when necessary. The attributes of licenses and platforms that matter most to libraries are those that make e-books easy to find and access, preferably on any device. If the NLNZ initiative were to result in an e-books lending platform, then a big design priority should be seamless integration with existing library management software and online catalogues. NLNZ has already recognised this need in the development of Kotui, its library management software solution that incorporates a library's e-resources into federated search results. This expertise could be built on in the development of any library e-book platform that might result from the initiative. 


\section{APPENDIX A: Information sheet sent with survey invitation}

Kia ora,

I am seeking the input of New Zealand public libraries for a Master of Information Studies research project into library e-book licensing. The findings of the project will also contribute to the National Library of New Zealand's (NLNZ) Collaborative Services E-books initiative. I am currently employed at NLNZ.

The growth in e-reader use and consequent rise in e-book consumption in recent years has led to a strong need for libraries to facilitate access to e-books for educational and recreational use. This increasingly means that libraries are purchasing licences to access content, rather than the content itself. In this transitional time, libraries, publishers and third-party vendors are exploring the appropriate licensing conditions for library e-books.

The purpose of my online survey is to gather information about public library requirements for licensing agreements to provide access to e-books for their users. The anonymous survey will take approximately fifteen minutes to complete, and only one response is required per library system. If you do not complete the survey yourself, could you please delegate it to an appropriate staff member (eg. in Collection Management or Electronic Resources).

This is a student project undertaken to meet the requirements of the Master of Information Studies at Victoria University (VUW). It has obtained ethical approval from the School of Information Management Human Ethics Committee. The results of this research will be used in a research report which will be hosted in VUW institutional repository, and the findings may also be published in articles in professional journals, or presented at conferences.

A copy of the report will be provided to the Association of Public Library managers. The findings of the research will also contribute to the NLNZ E-books initiative, a collaborative project exploring opportunities to provide aggregated access to e-book content to New Zealanders through public libraries and schools whilst recognising the rights of producers and distributors. This initiative is being led by the Collaborative Services team at NLNZ, which does related similar work by facilitating access to other electronic resources as the lead agency for the EPIC (Electronic Purchasing in Collaboration) consortium

All survey responses are anonymous, and no information that identifies the respondent or their library is being collected. Only I and my supervisor will have access to the survey data, and it will not be provided to any third parties. Identifying information from free-text responses will be excluded from the report. All data gathered from the survey will be kept in a password-protected file for two years after the conclusion of the research, and then destroyed.

$<$ Link to online survey $>$

For more information please feel free to contact the researcher:

Amy Joseph, MIS candidate, VUW

josephamy@myvuw.ac.nz

044623991

Academic supervisor:

Dr Brenda Chawner, FLIANZA

brenda.chawner@vuw.ac.nz

044635780 


\section{APPENDIX B: Survey questions}

Key:

O Multi-choice response, only one response option permitted per question

Multi-choice response, multiple response options may be selected

Free text response field

Respondent asked to input number, either by typing or by moving a slider 
Q1 The growth in e-reader use and consequent rise in e-book consumption in recent years has led to a strong need for libraries to facilitate access to e-books for educational and recreational use. This increasingly means that libraries are purchasing licences to access content, rather than the content itself. In this transitional time, libraries, publishers and third-party vendors are exploring the appropriate licensing conditions for library e-books.

The purpose of this online survey is to gather information about public library requirements for licensing agreements to provide access to e-books for their users. The survey will take approximately fifteen minutes to complete.

This is a student project undertaken to meet the requirements of the Master of Information Studies. The results of this research will be used in a research report which will be hosted in Victoria University of Wellington's (VUW) institutional repository, and the findings may also be published in articles in professional journals, or presented at conferences.

A copy of the report will be provided to the Association of Public Library managers. The findings of the research will also contribute to the National Library of New Zealand's (NLNZ) E-books initiative, a collaborative project exploring opportunities to provide aggregated access to e-book content to New Zealanders through public libraries and schools whilst recognising the rights of producers and distributors. This initiative is being led by the Collaborative Services team at NLNZ, which does related similar work by facilitating access to other electronic resources as the lead agency for the EPIC (Electronic Purchasing in Collaboration) consortium.

All survey responses are anonymous, and no information that identifies you, or the library you work for, is being collected. Only I and my supervisor will have access to the survey data, and it will not be provided to any third parties. Any identifying information from free-text responses will be excluded from the report. All data gathered from the survey will be kept in a password-protected file for two years after the conclusion of the research, and then destroyed.

By clicking 'Continue to survey' you are implying consent to participate in this research. Thank you very much for your time.

For more information please feel free to contact the researcher:

Amy Joseph, MIS candidate, VUW

josephamy@myvuw.ac.nz

044623991

Academic supervisor:

Dr Brenda Chawner, FLIANZA

brenda.chawner@vuw.ac.nz

044635780

Continue to survey

No thanks, I do not wish to participate 
Q2 What size is your library population base?

$\mathrm{O}<30,000$

O $30,000-49,999$

(50,000-99,999

$\geq 100,000$

Q3 Is your library a member of Aotearoa People's Network Kaharoa (APNK)?

O Yes

O No

Q4 Is your library a member of Electronic Purchasing in Collaboration (EPIC)?

$\mathrm{O}$ Yes

O No

Q5 Does your library have a specialised discovery tool that enables patrons to simultaneously search across their library catalogue and other electronic collections offered through the library (eg. Ebsco Discovery Services via Kotui, Aquabrowser)?

O Yes

O No

Not yet, but we have plans in place to do so

Q6 Do you currently provide e-books to your members?

"An e-book is defined as a book-length publication, consisting of text (and, sometimes, images) in digital form, formatted to be read on the electronic screens of user devices such as e-readers, computers and mobile phones" - OECD (2012). Include audiobooks available via download.

O Yes

O No

If Yes Is Selected, Then Skip To Q8

Q7 Do you plan on providing e-books to your members within the next two years?

O Yes

O No

If No Is Selected, Then Skip To Q10 
Answer If Q6 Yes Is Selected

Q8 How long have you been providing e-books to your members?

Less than 6 months

O 6 months - 1 year

O 1 year -18 months

18 months -2 years

More than 2 years

\section{Answer If Q6 Yes Is Selected}

Q9 Who are your current vendors/distributors for e-books?

Wheelers

- Overdrive via consortium

$\square$ Overdrive via individual library system contract

$\square \mathrm{EBL}$

$\square$ Gale Cengage

$\square$ Public Library Online

O Other

\section{Answer If Q7 No Is Selected}

Q10 Why don't you plan on providing e-books to your members within the next two years? Please select all reasons that apply and rank them in order of importance (most important at the top).

Drag all applicable factors here and rank them

There is not enough demand from our members

There is not enough money in our budget

We cannot provide the technical infrastructure

Other

\section{Answer If Q10 Other Is Selected}

Q11 What other reason/s does your library have for not planning to offer e-books within the next two years? 
Q12 Please provide any additional comments you wish to make regarding this survey or library licensing of e-books generally.

Q13 What percentage of your acquisitions budget are you currently spending on providing electronic materials?

Percentage of total acquisitions budget currently spent on e-resources (including e-books but also databases, subscription websites, etc)

Percentage of total acquisitions budget currently spent on e-books ("book-length publications, consisting of text (and, sometimes, images) in digital form, formatted to be read on the electronic screens of user devices" - include audiobooks available via download)

Q14 What percentage of your acquisitions budget do you anticipate spending on providing electronic materials in a year's time?

Percentage of total acquisitions budget spent on e-resources in a year's time (including e-books but also databases, subscription websites, etc) Percentage of total acquisitions budget spent on e-books in a year's time

Q15 What percentage of your acquisitions budget do you anticipate spending on providing electronic materials in five years' time? Percentage of total acquisitions budget spent on e-resources in five years' time (including e-books but also databases, subscription websites, etc) Percentage of total acquisitions budget spent on e-books in five years' time

\section{Answer If Q6 Yes Is Selected}

Q16 What proportion of your library's e-books are currently paid for from the CAPEX budget? From the OPEX budget? (Answers must add up to 100 percent.) CAPEX OPEX

\section{Answer If Q6 Yes Is Selected}

Q17 Do you anticipate the proportions identified in the previous question changing within the next five years?

O Yes

O No 
Q18 What proportion of your library's e-books do you anticipate being paid for from the CAPEX budget in five years' time? From the OPEX budget? (Answers must add up to 100 percent.) CAPEX OPEX

\section{Answer If Q17 Yes Is Selected}

Q19 What are the reasons behind the anticipated change in proportion of e-book budget coming from your CAPEX and OPEX budgets?

Q20 If there were no barriers to acquisition/provision of access, what proportion of your e-book collection would consist of New Zealand titles? Ideal percentage of New Zealand titles in e-book collection

Q21 How acceptable are the following business models for provision of e-book access?

\begin{tabular}{|c|c|c|c|c|c|}
\hline $\begin{array}{c}\text { Perpetual access } \\
\begin{array}{c}\text { License that expires } \\
\text { after a set number of } \\
\text { loans }\end{array}\end{array}$ & 0 & $\begin{array}{c}\text { Would consider if } \\
\text { no other options } \\
\text { were available }\end{array}$ & $\begin{array}{c}\text { Acceptable } \\
\text { acceptable }\end{array}$ & Optimal \\
$\begin{array}{c}\text { License that expires } \\
\text { after a set time period } \\
\begin{array}{c}\text { Subscription packages } \\
\text { (ie. the library does } \\
\text { not select individual } \\
\text { titles, but gets a } \\
\text { package based on }\end{array}\end{array}$ & 0 & 0 & 0 & 0 & 0 \\
$\begin{array}{c}\text { topic area, publisher, } \\
\text { etc) }\end{array}$ & 0 & 0 & 0 & 0 & 0 \\
$\begin{array}{c}\text { Pay-per-use } \\
\text { Combination of } \\
\text { perpetual access with } \\
\text { pay-per-use (ie. lower } \\
\text { initial fee, but small } \\
\text { fee charged for each } \\
\text { use) }\end{array}$ & 0 & 0 & 0 & 0 & 0 \\
$\begin{array}{c}\text { Rent-to-own } \\
\begin{array}{c}\text { Ownership of e-book } \\
\text { files on own server or } \\
\text { cloud storage }\end{array}\end{array}$ & 0 & 0 & 0 & 0 & 0 \\
\hline
\end{tabular}


Q22 Are there any models for provision of e-book access not listed above that you think would work for your library?

Answer If How acceptable are the following business models ...? License that expires after a set number of loans - Unacceptable Is Not Selected

Q23 What is the minimum number loans you would accept for a license that expires after a set number of loans? Number of loans

Answer If How acceptable are the following business models...? License that expires after a set time period - Unacceptable Is Not Selected

Q24 What is the minimum time period you would accept for a license that expires after a set time period? Time period (in months)

Q25 If you had to choose between licenses that expire after a set number of loans and licenses that expire after a set time period, which would you prefer?

$O$ Set number of loans

Set time period 
Q26 How important are the following attributes of e-book licenses for your library?

\begin{tabular}{|c|c|c|c|c|c|}
\hline & $\begin{array}{l}\text { Not } \\
\text { required }\end{array}$ & $\begin{array}{c}\text { Neutral/No } \\
\text { opinion }\end{array}$ & $\begin{array}{c}\text { Nice to have, } \\
\text { but not } \\
\text { necessary }\end{array}$ & $\begin{array}{l}\text { Would make } \\
\text { license more } \\
\text { attractive }\end{array}$ & Necessary \\
\hline $\begin{array}{l}\text { Access does not expire after } \\
\text { set time period }\end{array}$ & $\mathrm{O}$ & O & O & $\mathrm{O}$ & 0 \\
\hline $\begin{array}{l}\text { Access does not expire after } \\
\text { set number of loans }\end{array}$ & $\mathrm{O}$ & O & O & $\mathrm{O}$ & $\mathrm{O}$ \\
\hline $\begin{array}{l}\text { No embargo period for the } \\
\text { library e-book edition } \\
\text { compared to the } \\
\text { commercially available e- } \\
\text { book }\end{array}$ & O & 0 & $\mathrm{O}$ & $\mathrm{O}$ & $\mathrm{O}$ \\
\hline $\begin{array}{l}\text { Provision of a preservation } \\
\text { file of the e-book for the } \\
\text { library to own }\end{array}$ & O & O & O & $\mathrm{O}$ & 0 \\
\hline Integration with our ILS & $\mathrm{O}$ & $\mathrm{O}$ & $\mathrm{O}$ & $\mathrm{O}$ & O \\
\hline $\begin{array}{l}\text { Integration with our } \\
\text { acquisition workflows for } \\
\text { print materials }\end{array}$ & $\mathrm{O}$ & $\mathrm{O}$ & $\mathrm{O}$ & $\mathrm{O}$ & 0 \\
\hline $\begin{array}{l}\text { Ability to charge user fees } \\
\text { for e-books }\end{array}$ & O & O & O & O & $\mathrm{O}$ \\
\hline $\begin{array}{l}\text { Offline access for } \\
\text { borrowers during the loan } \\
\text { period }\end{array}$ & $\mathrm{O}$ & $\mathrm{O}$ & O & $\mathrm{O}$ & $\mathrm{O}$ \\
\hline $\begin{array}{l}\text { Simultaneous access for } \\
\text { multiple users }\end{array}$ & $\mathrm{O}$ & O & $\mathrm{O}$ & $\mathrm{O}$ & $\mathrm{O}$ \\
\hline $\begin{array}{l}\text { Access to titles from } \\
\text { independent publishers and } \\
\text { self-published authors }\end{array}$ & O & 0 & O & $\mathrm{O}$ & 0 \\
\hline $\begin{array}{c}\text { Access to New Zealand } \\
\text { titles }\end{array}$ & $\mathrm{O}$ & O & $\mathrm{O}$ & $\mathrm{O}$ & $\mathrm{O}$ \\
\hline $\begin{array}{c}\text { Compatibility with all } \\
\text { devices }\end{array}$ & O & O & $\mathrm{O}$ & $\mathrm{O}$ & O \\
\hline $\begin{array}{l}\text { Links from discovery } \\
\text { system for users to purchase } \\
\text { titles }\end{array}$ & O & $\mathrm{O}$ & O & $\mathrm{O}$ & $\mathrm{O}$ \\
\hline $\begin{array}{c}\text { Triggers for purchases of } \\
\text { additional copies based on } \\
\text { user demand (eg. hold } \\
\text { requests) }\end{array}$ & O & O & $\mathrm{O}$ & $\mathrm{O}$ & $\mathrm{O}$ \\
\hline $\begin{array}{l}\text { Integration of titles supplied } \\
\text { by different vendors } \\
\text { through one discovery } \\
\text { interface }\end{array}$ & $\mathrm{O}$ & O & $\mathrm{O}$ & O & 0 \\
\hline
\end{tabular}


Q27 Are there any e-book licensing conditions not listed above that you think would be attractive for your library?

Q28 What would be the one innovation that would make e-book lending in your library the biggest success for your customers? 


\section{APPENDIX C: Statistical tests for correlation of library size with other variables}

Many of the results are calculated to compare differences between libraries of different sizes. However, the small sample size and $50.8 \%$ response rate meant that it is difficult to draw statistically significant inferences from the data.

The following cross-tabulation tables with chi-squared statistics were generated by the Qualtrics survey software to check for interrelationships. The chi-squared statistic is used to determine whether differences in frequencies between groups are likely to have occurred by chance. It can be seen that very few results suggested a statistically significant relationship between the two variables in question (chi-square value at the given degree of freedom yielding a $p$-value $<0.05$, or less than five percent chance that an observed relationship is due to chance). These results may not necessarily be accurate given the low total number of respondents: chi-square values may not be accurate when the expected distribution if the null hypothesis is true (ie. no difference between groups) is less than five for a given cell in the cross-tabulation table. This was the case for the results of this survey: it can be seen from the tables below that in all cases where library size was cross-tabulated against another variable, the chi-squared statistic is not necessarily valid.

For the questions where respondents were asked to rate license models or attributes, no statistically significant relationships emerged from the cross-tabulations. A second set of cross-tabulations was calculated by collapsing the response categories in the following way:

For the question, "How acceptable are the following business models for provision of ebook access?" the categories were collapsed to:

- Unacceptable / Would consider if no other options were available

- Acceptable / Highly acceptable / Optimal

For the question "How important are the following attributes of e-book licenses for your library?" the categories were collapsed to:

- Not required / Neutral/No opinion

- Nice to have, but not necessary

- Would make license more attractive / Necessary 
Even after collapsing these categories, the expected frequencies for the null hypothesis were still less than five in many cells, meaning the chi-squared values were not necessarily valid. Only one statistically-significant correlation emerged anyway: there was possibly a relationship between library size and attitude towards the license model that expires after a set number of loans, with small and extra large libraries more likely to find loan-based limits acceptable than medium and large libraries (chi square 2.26 (not necessarily accurate); degrees of freedom 3 ; $p$-value 0.02 ). 


\section{General information cross-tabulated by library size}

\begin{tabular}{|c|c|c|c|c|c|c|}
\hline & & \multicolumn{4}{|c|}{$\begin{array}{l}\text { What size is your library } \\
\text { population base? }\end{array}$} & \multirow[b]{2}{*}{ Total } \\
\hline & & & $\begin{array}{l}30,000- \\
49,999\end{array}$ & $\begin{array}{l}50,000- \\
99,999\end{array}$ & $\geq 100,000$ & \\
\hline \multirow{3}{*}{ Is your library a member of Aotearoa People's Network Kaharoa (APNK)? } & Yes & 8 & 8 & 4 & 5 & 25 \\
\hline & No & 2 & 1 & 3 & 3 & 9 \\
\hline & Total & 10 & 9 & 7 & 8 & 34 \\
\hline \multirow{3}{*}{ Is your library a member of Electronic Purchasing in Collaboration (EPIC)? } & Yes & 7 & 9 & 7 & 7 & 30 \\
\hline & No & 3 & 0 & 0 & 1 & 4 \\
\hline & Total & 10 & 9 & 7 & 8 & 34 \\
\hline \multirow{4}{*}{$\begin{array}{l}\text { Does your library have a specialised discovery tool that enables patrons } \\
\text { to simultaneously search ac... }\end{array}$} & Yes & 2 & 5 & 2 & 0 & 9 \\
\hline & No & 5 & 3 & 3 & 4 & 15 \\
\hline & $\begin{array}{l}\text { Not yet, but we have plans in } \\
\text { place to do so }\end{array}$ & 3 & 1 & 2 & 4 & 10 \\
\hline & Total & 10 & 9 & 7 & 8 & 34 \\
\hline \multirow{2}{*}{$\begin{array}{l}\text { Do you currently provide e-books to your members? "An e-book is defined } \\
\text { as a book-length publ... }\end{array}$} & Yes & 10 & 9 & 6 & 7 & 32 \\
\hline & No & 0 & 0 & 1 & 1 & 2 \\
\hline & Total & 10 & 9 & 7 & 8 & 34 \\
\hline \multirow{2}{*}{$\begin{array}{l}\text { Do you plan on providing e-books to your members within the next two } \\
\text { years? }\end{array}$} & Yes & 0 & 0 & 1 & 1 & 2 \\
\hline & No & 0 & 0 & 0 & 0 & 0 \\
\hline & Total & 0 & 0 & 1 & 1 & 2 \\
\hline \multirow{6}{*}{ How long have you been providing e-books to your members? } & Less than 6 months & 1 & 2 & 0 & 0 & 3 \\
\hline & 6 months - 1 year & 0 & 0 & 1 & 0 & 1 \\
\hline & 1 year - 18 months & 7 & 5 & 5 & 5 & 22 \\
\hline & 18 months -2 years & 1 & 2 & 0 & 0 & 3 \\
\hline & More than 2 years & 1 & 0 & 0 & 2 & 3 \\
\hline & Total & 10 & 9 & 6 & 7 & 32 \\
\hline \multirow{8}{*}{ Who are your current vendors/distributors for e-books? } & Wheelers & 2 & 4 & 1 & 3 & 10 \\
\hline & Overdrive via consortium & 8 & 5 & 5 & 2 & 20 \\
\hline & $\begin{array}{l}\text { Overdrive via individual library } \\
\text { system contract }\end{array}$ & 1 & 0 & 0 & 2 & 3 \\
\hline & EBL & 0 & 0 & 0 & 0 & 0 \\
\hline & Gale Cengage & 0 & 1 & 0 & 1 & 2 \\
\hline & Public Library Online & 0 & 0 & 0 & 0 & 0 \\
\hline & Other & 0 & 0 & 2 & 1 & 3 \\
\hline & Total & 10 & 9 & 6 & 7 & 32 \\
\hline
\end{tabular}

\begin{tabular}{|c|l|l|}
\cline { 3 - 3 } \multicolumn{2}{l|}{} & $\begin{array}{c}\text { What size is your library } \\
\text { population base? }\end{array}$ \\
\hline $\begin{array}{c}\text { Is your library a member of } \\
\text { Aotearoa People's Network } \\
\text { Kaharoa (APNK)? }\end{array}$ & Chi Square & $2.77^{*}$ \\
\cline { 2 - 3 } & Degrees of Freedom & 3 \\
\cline { 2 - 3 } & p-value & 0.43 \\
\hline
\end{tabular}

"Note: The Chi-Square approximation may be inaccurate-expected frequency less than 5.

\begin{tabular}{|l|l|l|}
\cline { 3 - 3 } \multicolumn{2}{c|}{} & \multicolumn{1}{|c|}{$\begin{array}{c}\text { What size is your library } \\
\text { population base? }\end{array}$} \\
\hline $\begin{array}{c}\text { Is your library a member of } \\
\text { Electronic Purchasing in } \\
\text { Collaboration (EPIC)? }\end{array}$ & Chi Square & $5.34^{*}$ \\
\cline { 2 - 3 } & Degrees of Freedom & 3 \\
\cline { 2 - 3 } & p-value & 0.15 \\
\hline
\end{tabular}

"Nole: The Chi-Square approximation may be inaccurale-expected frequency less than 5 . 


\begin{tabular}{|c|l|l|}
\cline { 3 - 3 } \multicolumn{2}{c|}{} & \multicolumn{1}{|c|}{$\begin{array}{c}\text { What size is your library } \\
\text { population base? }\end{array}$} \\
\hline \multirow{2}{*}{$\begin{array}{c}\text { Does your library have a } \\
\text { specialised discovery tool } \\
\text { that enables patrons to } \\
\text { simultaneously search ac... }\end{array}$} & Chi Square & $7.73^{*}$ \\
\cline { 2 - 3 } & Degrees of Freedom & 6 \\
\cline { 2 - 3 } & p-value & 0.26 \\
\hline
\end{tabular}

*Note: The Chi-Square approximation may be inaccurate - expected frequency less than 5.

\begin{tabular}{|c|l|l|}
\cline { 3 - 3 } \multicolumn{2}{c|}{} & \multicolumn{1}{|c|}{$\begin{array}{c}\text { What size is your library } \\
\text { population base? }\end{array}$} \\
\hline \multirow{2}{*}{$\begin{array}{c}\text { Do you currently provide e- } \\
\text { books to your members? }\end{array}$} & Chi Square & $2.71^{*}$ \\
\cline { 2 - 3 } $\begin{array}{c}\text { "An e-book is defined as a } \\
\text { honk-length publ... }\end{array}$ & Degrees of Freedom & 3 \\
\cline { 2 - 3 } & p-value & 0.44 \\
\hline
\end{tabular}

*Note: The Chi-Square approximation may be inaccurate - expected frequency less than 5.

\begin{tabular}{|l|l|l|}
\multicolumn{2}{c|}{} & \multicolumn{1}{|c|}{$\begin{array}{c}\text { What size is your library } \\
\text { population base? }\end{array}$} \\
\hline \multirow{2}{*}{$\begin{array}{l}\text { Do you plan on providing } \\
\text { e-books to your members } \\
\text { within the next two years? }\end{array}$} & Chi Square & $0.00^{*}$ \\
\cline { 2 - 3 } & Degrees of Freedom & 3 \\
\cline { 2 - 3 } & p-value & 1.00 \\
\hline
\end{tabular}

"Note: The Chi-Square approximation may be inaccurate - expected frequency less than 5.

\begin{tabular}{|c|l|l|}
\cline { 3 - 3 } \multicolumn{2}{|c|}{} & \multicolumn{1}{|c|}{$\begin{array}{c}\text { What size is your library } \\
\text { population base? }\end{array}$} \\
\hline \multirow{2}{*}{$\begin{array}{c}\text { How long have you been } \\
\text { providing e-books to your } \\
\text { me mbers? }\end{array}$} & Chi Square & $14.53^{*}$ \\
\cline { 2 - 3 } \begin{tabular}{c} 
megrees of Freedom \\
\cline { 2 - 3 }
\end{tabular} & 12 \\
\cline { 2 - 3 } & D-value & 0.27 \\
\hline
\end{tabular}

"Note: The Chi-Square approximation may be inaccurate - expected frequency less than 5.

\begin{tabular}{|c|l|l|}
\cline { 3 - 3 } \multicolumn{2}{|c|}{} & \multicolumn{1}{|c|}{$\begin{array}{c}\text { What size is your library } \\
\text { population base? }\end{array}$} \\
\hline \multirow{2}{*}{$\begin{array}{c}\text { Who are your current } \\
\text { vendors/distributors for e- } \\
\text { books? }\end{array}$} & Chi Square & $15.74^{*}$ \\
\cline { 2 - 3 } \begin{tabular}{c} 
bogrees of Freedom \\
\cline { 2 - 3 }
\end{tabular} & 18 \\
\cline { 2 - 3 } & D-value & 0.61 \\
\hline
\end{tabular}

*Note: The Chi-Square approximation may be inaccurate - expected frequency less than 5. 
Preferences for models cross-tabulated by library size

\begin{tabular}{|c|c|c|c|c|c|c|}
\hline & & \multicolumn{4}{|c|}{$\begin{array}{l}\text { What size is your library } \\
\text { population base? }\end{array}$} & \multirow[b]{2}{*}{ Total } \\
\hline & & & $\begin{array}{l}30,000- \\
49,999\end{array}$ & $\begin{array}{l}50,000- \\
99,999\end{array}$ & $\geq 100,000$ & \\
\hline \multirow{3}{*}{$\begin{array}{c}\text { How acceptable are the following business models for public library provision of e- } \\
\text { book access? - Perpetual access }\end{array}$} & $\begin{array}{l}\text { Unacceptable, Would } \\
\text { consider if no other options } \\
\text { were available }\end{array}$ & 1 & 0 & 1 & 0 & 2 \\
\hline & $\begin{array}{l}\text { Acceptable, Highly } \\
\text { acceptable, Optimal }\end{array}$ & 9 & 9 & 6 & 8 & 32 \\
\hline & Total & 10 & 9 & 7 & 8 & 34 \\
\hline \multirow{3}{*}{$\begin{array}{l}\text { How acceptahle are the following husiness models for public. library provision of e- } \\
\text { book access? - License that expires after a set number of loans }\end{array}$} & $\begin{array}{l}\text { Unacceptable, Would } \\
\text { consider if no other options } \\
\text { were available }\end{array}$ & 5 & 9 & 7 & 5 & 26 \\
\hline & $\begin{array}{l}\text { Acceptable, Highly } \\
\text { acceptable, Optimal }\end{array}$ & 5 & 0 & 0 & 3 & 8 \\
\hline & Total & 10 & 9 & 7 & 8 & 34 \\
\hline \multirow{3}{*}{$\begin{array}{l}\text { How acceptable are the following business models for public library provision of e- } \\
\text { book access? - License that expires after a set time period }\end{array}$} & $\begin{array}{l}\text { Unacceptable, Would } \\
\text { consider if no other options } \\
\text { were available }\end{array}$ & 5 & 8 & 6 & 4 & 23 \\
\hline & $\begin{array}{l}\text { Acceptable, Highly } \\
\text { acceptable, Optimal }\end{array}$ & 5 & 1 & 1 & 4 & 11 \\
\hline & Total & 10 & 9 & 7 & 8 & 34 \\
\hline \multirow{2}{*}{$\begin{array}{l}\text { How acceptable are the following business models for public library provision of e- } \\
\text { book access? - Subscription packages (ie. the library does not select individual titles, } \\
\text { but gets a package based on topic area, publisher, etc) }\end{array}$} & $\begin{array}{l}\text { Unacceptable, Would } \\
\text { consider if no other options } \\
\text { were available }\end{array}$ & 5 & 5 & 5 & 6 & 21 \\
\hline & $\begin{array}{l}\text { Acceptable, Highly } \\
\text { acceptable, Optimal }\end{array}$ & 5 & 4 & 2 & 2 & 13 \\
\hline & Total & 10 & 9 & 7 & 8 & 34 \\
\hline \multirow{3}{*}{$\begin{array}{l}\text { How acceptable are the following business models for public library provision of e- } \\
\text { book access? - Pay-per-use }\end{array}$} & $\begin{array}{l}\text { Unacceptable, Would } \\
\text { consider if no other options } \\
\text { were available }\end{array}$ & 7 & 5 & 5 & 5 & 22 \\
\hline & $\begin{array}{l}\text { Acceptable, Highly } \\
\text { acceptable, Optimal }\end{array}$ & 3 & 4 & 2 & 3 & 12 \\
\hline & Total & 10 & 9 & 7 & 8 & 34 \\
\hline \multirow{3}{*}{$\begin{array}{c}\text { How acceptable are the following business models for public library provision of e- } \\
\text { book access? - Combination of perpetual access with pay-per-use (ie. lower initial } \\
\text { payment for title, but small fee charged for each use) }\end{array}$} & $\begin{array}{l}\text { Unacceptable, Would } \\
\text { consider if no other options } \\
\text { were available }\end{array}$ & 4 & 4 & 5 & 4 & 17 \\
\hline & $\begin{array}{l}\text { Acceptable, Highly } \\
\text { acceptable, Optimal }\end{array}$ & 5 & 4 & 2 & 4 & 15 \\
\hline & Total & 9 & 8 & 7 & 8 & 32 \\
\hline \multirow{3}{*}{$\begin{array}{l}\text { How acceptable are the following business models for public library provision of e- } \\
\text { book access? - Rent-to-own }\end{array}$} & $\begin{array}{l}\text { Unacceptable, Would } \\
\text { consider if no other options } \\
\text { were available }\end{array}$ & 6 & 7 & 5 & 5 & 23 \\
\hline & $\begin{array}{l}\text { Acceptable, Highly } \\
\text { acceptable, Optimal }\end{array}$ & 4 & 2 & 2 & 3 & 11 \\
\hline & Total & 10 & 9 & 7 & 8 & 34 \\
\hline \multirow{2}{*}{$\begin{array}{l}\text { If you had to choose between licenses that expire after a set number of loans and } \\
\qquad \text { licenses that expi... }\end{array}$} & Set number of loans & 5 & 4 & 4 & 5 & 18 \\
\hline & Set time period & 4 & 5 & 3 & 3 & 15 \\
\hline & Total & 9 & 9 & 7 & 8 & 33 \\
\hline
\end{tabular}

\begin{tabular}{|c|l|l|}
\cline { 3 - 3 } \multicolumn{2}{c|}{} & $\begin{array}{c}\text { What size is your library } \\
\text { population base? }\end{array}$ \\
\hline $\begin{array}{c}\text { How acceptable are the } \\
\text { following business models } \\
\text { for public library provision } \\
\text { of e-book access? - } \\
\text { Perpetual access }\end{array}$ & Chi Square & $2.26^{*}$ \\
\cline { 2 - 3 } & Degrees of Freedom & 3 \\
\cline { 2 - 3 } & p-value & 0.52 \\
\hline
\end{tabular}

"Note: The Chi-Square approximation may be inaccurate - expected frequency less than 5. 


\begin{tabular}{|c|l|l|}
\cline { 3 - 3 } \multicolumn{2}{c|}{} & \multicolumn{1}{c|}{$\begin{array}{c}\text { What size is your library } \\
\text { population base? }\end{array}$} \\
\hline $\begin{array}{c}\text { How acceptable are the } \\
\text { following business models } \\
\text { for public library provision } \\
\text { of e-book access? } \\
\text { License that expires after a } \\
\text { set number of loans }\end{array}$ & Chi Square & $9.69^{*}$ \\
\cline { 2 - 3 } & Degrees of Freedom & 3 \\
\hline
\end{tabular}

*Note: The Chi-Square approximation may be inaccurate - expected frequency less than 5.

\begin{tabular}{|c|l|l|}
\cline { 3 - 3 } \multicolumn{2}{c|}{} & \multicolumn{1}{|c|}{$\begin{array}{c}\text { What size is your library } \\
\text { population base? }\end{array}$} \\
\hline \begin{tabular}{c} 
How acceptable are the \\
following business models \\
for public lihrary provision \\
of e-book access? - \\
\cline { 3 - 3 } $\begin{array}{c}\text { License that expires after a } \\
\text { set time period }\end{array}$
\end{tabular} & Degrees of Freedom & $3.46^{*}$ \\
\cline { 2 - 3 } & p-value & 0.14 \\
\hline
\end{tabular}

"Note: The Chi-Square approximation may be inaccurate - expected frequency less than 5.

\begin{tabular}{|c|c|c|}
\hline & & $\begin{array}{c}\text { What size is your library } \\
\text { population base? }\end{array}$ \\
\hline \multirow{3}{*}{$\begin{array}{l}\text { How acceptable are the } \\
\text { following business models } \\
\text { for public library provision } \\
\text { of e-book access? - } \\
\text { Subscription packages (ie. } \\
\text { the library does not select } \\
\text { individual titles, but gets a } \\
\text { package based on topic } \\
\text { area, publisher, etc) }\end{array}$} & Chi Square & $1.60^{*}$ \\
\hline & Degrees of Freedom & 3 \\
\hline & $p$-value & 0.66 \\
\hline
\end{tabular}

*Note: The Chi-Square approximation may be inaccurate - expected frequency less than 5.

\begin{tabular}{|c|l|l|}
\cline { 3 - 3 } \multicolumn{2}{c|}{} & \multicolumn{1}{c|}{$\begin{array}{c}\text { What size is your library } \\
\text { population base? }\end{array}$} \\
\hline $\begin{array}{c}\text { How acceptable are the } \\
\text { following business models } \\
\text { for public library provision } \\
\text { of e-book access? - Pay- } \\
\text { per-use }\end{array}$ & Chi Square & $0.61^{*}$ \\
\cline { 2 - 3 } \begin{tabular}{c} 
pegrees of Freedom \\
\cline { 2 - 3 }
\end{tabular} & D-value & 3 \\
\hline
\end{tabular}

*Note: The Chi-Square approximation may be inaccurate - expected frequency less than 5.

\begin{tabular}{|c|c|c|}
\hline & & $\begin{array}{c}\text { What size is your library } \\
\text { population base? }\end{array}$ \\
\hline \multirow{3}{*}{$\begin{array}{l}\text { How acceptable are the } \\
\text { following business models } \\
\text { for public library provision } \\
\text { of e-book access? - } \\
\text { Combination of perpetual } \\
\text { access with pay-per-use } \\
\text { (ie. lower initial payment for } \\
\text { title, but small fee charged } \\
\text { for each use) }\end{array}$} & Chi Square & $1.28^{*}$ \\
\hline & Degrees of Freedom & 3 \\
\hline & $p$-value & 0.73 \\
\hline
\end{tabular}

*Note: The Chi-Square approximation may be inaccurate - expected frequency less than 5. 


\begin{tabular}{|c|l|l|}
\cline { 3 - 3 } \multicolumn{2}{c|}{} & \multicolumn{1}{c|}{$\begin{array}{c}\text { What size is your library } \\
\text { population base? }\end{array}$} \\
\hline $\begin{array}{c}\text { How acceptable are the } \\
\text { following business models } \\
\text { for public library provision } \\
\text { of e-book access? - Rent- } \\
\text { to-own }\end{array}$ & Chi Square & $0.83^{*}$ \\
\cline { 2 - 3 } & Degrees of Freedom & 3 \\
\cline { 2 - 3 } & p-value & 0.84 \\
\hline
\end{tabular}

"Note: The Chi-Square approximation may be inaccurate - expected frequency less than 5.

\begin{tabular}{|c|l|l|}
\cline { 3 - 3 } \multicolumn{2}{c|}{} & $\begin{array}{c}\text { What size is your library } \\
\text { population base? }\end{array}$ \\
\hline $\begin{array}{c}\text { If you had to choose } \\
\text { between licenses that } \\
\text { expire after a set number of } \\
\text { Inans and licenses that } \\
\text { expi... }\end{array}$ & Chi Square & $0.60^{*}$ \\
\cline { 2 - 3 } & Degrees of Freedom & 3 \\
\cline { 2 - 3 } & p-value & 0.90 \\
\hline
\end{tabular}

"Note: The Chi-Square approximation may be inaccurate - expected frequency less than 5. 


\begin{tabular}{|l|l|l|}
\cline { 3 - 3 } \multicolumn{2}{c|}{} & \multicolumn{1}{|c|}{$\begin{array}{c}\text { What size is your library } \\
\text { population base? }\end{array}$} \\
\hline $\begin{array}{c}\text { How important are the } \\
\text { following attributes of e- } \\
\text { book licenses for your } \\
\text { library? - Access does not } \\
\text { expire after set time period }\end{array}$ & Chi Square & $4.64^{*}$ \\
\cline { 2 - 3 } & Degrees of Freedom & 6 \\
\cline { 2 - 3 } & & 0.59 \\
\hline
\end{tabular}

"Note: The Chi-Square approximation may be inaccurate - expected frequency less than 5.

\begin{tabular}{|c|l|l|}
\cline { 3 - 3 } \multicolumn{2}{c|}{} & \multicolumn{1}{|c|}{$\begin{array}{c}\text { What size is your library } \\
\text { population base? }\end{array}$} \\
\hline $\begin{array}{c}\text { How important are the } \\
\text { following attributes of e- } \\
\text { book licenses for your } \\
\text { lihrary? - Access does not } \\
\text { expire after set number of } \\
\text { loans }\end{array}$ & Chi Square & $4.89^{*}$ \\
\cline { 2 - 3 } & Degrees of Freedom & 6 \\
\cline { 3 - 3 } & p-value & 0.56 \\
\hline
\end{tabular}

"Note: The Chi-Square approximation may be inaccurate - expected frequency less than 5.

\begin{tabular}{|c|l|l|}
\cline { 3 - 3 } \multicolumn{2}{c|}{} & \multicolumn{1}{|c|}{$\begin{array}{c}\text { What size is your library } \\
\text { population base? }\end{array}$} \\
\hline $\begin{array}{c}\text { How important are the } \\
\text { following attributes of e- } \\
\text { book licenses for your } \\
\text { library? - No embargo } \\
\text { period for the library e- } \\
\text { book edition compared to } \\
\text { the print edition }\end{array}$ & Degrees of Freedom & $6.95^{*}$ \\
\cline { 2 - 3 } & p-value & 6.55 \\
\hline
\end{tabular}

"Note: The Chi-Square approximation may be inaccurate - expected frequency less than 5 .

\begin{tabular}{|c|l|l|}
\cline { 3 - 3 } \multicolumn{2}{c|}{} & \multicolumn{1}{|c|}{$\begin{array}{c}\text { What size is your library } \\
\text { population base? }\end{array}$} \\
\hline $\begin{array}{c}\text { How important are the } \\
\text { following attributes of } \mathrm{e}- \\
\text { book licenses for your } \\
\text { library? - Provision of } \\
\text { preservation files of specific } \\
\text { titles for the library to own } \\
\text { on their own server or cloud } \\
\text { storage }\end{array}$ & Chi Square & $7.86^{*}$ \\
\cline { 2 - 3 } & Degrees of Freedom & 6 \\
\hline
\end{tabular}

*Note: The Chi-Square approximation may be inaccurate - expected frequency less than 5.

\begin{tabular}{|c|l|l|}
\cline { 3 - 3 } \multicolumn{2}{c|}{} & $\begin{array}{c}\text { What size is your library } \\
\text { population base? }\end{array}$ \\
\hline $\begin{array}{c}\text { How important are the } \\
\text { following attributes of e- } \\
\text { book licenses for your } \\
\text { library? - Integration with } \\
\text { our ILS }\end{array}$ & Chi Square & $3.59^{*}$ \\
\cline { 2 - 3 } & Degrees of Freedom & 6 \\
\cline { 2 - 3 } & p-value & 0.73 \\
\hline
\end{tabular}

"Note: The Chi-Square approximation may be inaccurate - expected frequency less than 5.

\begin{tabular}{|c|l|l|}
\cline { 3 - 3 } \multicolumn{2}{c|}{} & \multicolumn{1}{|c|}{$\begin{array}{c}\text { What size is your library } \\
\text { population base? }\end{array}$} \\
\hline $\begin{array}{c}\text { How important are the } \\
\text { following attributes of e- } \\
\text { hook licenses for your } \\
\text { library? - Integration with } \\
\text { our acquisition workflows } \\
\text { for print materials }\end{array}$ & Chi Square & $6.44^{*}$ \\
\cline { 2 - 3 } & Degrees of Freedom & 6 \\
\hline
\end{tabular}

*Note: The Chi-Square approximation may be inaccurate - expected frequency less than 5. 


\begin{tabular}{|c|l|l|}
\cline { 3 - 3 } \multicolumn{2}{c|}{} & \multicolumn{1}{c|}{$\begin{array}{c}\text { What size is your library } \\
\text { population base? }\end{array}$} \\
\hline $\begin{array}{c}\text { How important are the } \\
\text { following attributes of } e- \\
\text { book licenses for your } \\
\text { library? - Ability to charge } \\
\text { user fees for e-books }\end{array}$ & Chi Square & $7.87^{*}$ \\
\cline { 2 - 3 } & Degrees of Freedom & 6 \\
\cline { 2 - 3 } & p-value & 0.25 \\
\hline
\end{tabular}

"Note: The Chi-Square approximation may be inaccurate - expected frequency less than 5.

\begin{tabular}{|c|l|l|}
\cline { 3 - 3 } \multicolumn{2}{c|}{} & $\begin{array}{c}\text { What size is your library } \\
\text { population base? }\end{array}$ \\
\hline $\begin{array}{c}\text { How important are the } \\
\text { following attributes of e- } \\
\text { book licenses for your } \\
\text { lihrary? - Offline access for } \\
\text { borrowers during the loan } \\
\text { period }\end{array}$ & Chi Square & $6.65^{*}$ \\
\cline { 2 - 3 } & Degrees of Freedom & 6 \\
\cline { 2 - 3 } & p-value & 0.35 \\
\hline
\end{tabular}

"Note: The Chi-Square approximation may be inaccurate - expected frequency less than 5.

\begin{tabular}{|c|l|l|}
\cline { 3 - 3 } \multicolumn{2}{c|}{} & \multicolumn{1}{|c|}{$\begin{array}{c}\text { What size is your library } \\
\text { population base? }\end{array}$} \\
\hline $\begin{array}{c}\text { How important are the } \\
\text { following attributes of e- } \\
\text { book licenses for your } \\
\text { library? - Simultaneous } \\
\text { access for multiple users }\end{array}$ & Chi Square & $7.48^{*}$ \\
\cline { 2 - 3 } & Degrees of Freedom & 6 \\
\cline { 2 - 3 } & p-value & 0.28 \\
\hline
\end{tabular}

*Note: The Chi-Square approximation may be inaccurate - expected frequency less than 5.

\begin{tabular}{|c|l|l|}
\cline { 3 - 3 } \multicolumn{2}{|c|}{} & \multicolumn{1}{|c|}{$\begin{array}{c}\text { What size is your library } \\
\text { population base? }\end{array}$} \\
\hline $\begin{array}{c}\text { How important are the } \\
\text { following attributes of } \mathrm{e}- \\
\text { book licenses for your } \\
\text { library? - Access to titles } \\
\text { from independent } \\
\text { publishers and self- } \\
\text { published authors }\end{array}$ & Chi Square & $10.18^{*}$ \\
\cline { 2 - 3 } & Degrees of Freedom & 6 \\
\cline { 2 - 3 } & p-value & 0.12 \\
\hline
\end{tabular}

*Note: The Chi-Square approximation may be inaccurate - expected frequency less than 5.

\begin{tabular}{|c|l|l|}
\cline { 3 - 3 } \multicolumn{2}{c|}{} & \multicolumn{1}{|c|}{$\begin{array}{c}\text { What size is your library } \\
\text { population base? }\end{array}$} \\
\hline $\begin{array}{c}\text { How important are the } \\
\text { following attributes of e- } \\
\text { book licenses for your } \\
\text { library? - Access to New } \\
\text { Zealand titles }\end{array}$ & Chi Square & $1.29^{*}$ \\
\cline { 2 - 3 } & Degrees of Freedom & 6 \\
\cline { 2 - 3 } & p-value & 0.97 \\
\hline
\end{tabular}

*Note: The Chi-Square approximation may be inaccurate - expected frequency less than 5.

\begin{tabular}{|c|l|l|}
\cline { 3 - 3 } \multicolumn{2}{c|}{} & \multicolumn{1}{c|}{$\begin{array}{c}\text { What size is your library } \\
\text { population base? }\end{array}$} \\
\hline $\begin{array}{c}\text { How important are the } \\
\text { following attributes of } e- \\
\text { book licenses for your } \\
\text { library? - Compatibility with } \\
\text { all devices }\end{array}$ & Chi Square & $3.22^{*}$ \\
\cline { 2 - 3 } & Degrees of Freedom & 6 \\
\cline { 2 - 3 } & p-value & 0.78 \\
\hline
\end{tabular}

"Note: The Chi-Square approximation may be inaccurate - expected frequency less than 5. 


\begin{tabular}{|c|l|l|}
\cline { 3 - 3 } \multicolumn{2}{c|}{} & \multicolumn{1}{|c|}{$\begin{array}{c}\text { What size is your library } \\
\text { population base? }\end{array}$} \\
\hline $\begin{array}{c}\text { How important are the } \\
\text { following attributes of } \mathrm{e}- \\
\text { book licenses for your } \\
\text { library? - Links to allow } \\
\text { users to purchase titles }\end{array}$ & Chi Square & $4.41^{*}$ \\
\cline { 2 - 3 } & Degrees of Freedom & 6 \\
\cline { 2 - 3 } & p-value & 0.62 \\
\hline
\end{tabular}

*Note: The Chi-Square approximation may be inaccurate - expected frequency less than 5.

\begin{tabular}{|c|l|l|}
\cline { 3 - 3 } \multicolumn{2}{c|}{} & \multicolumn{1}{|c|}{$\begin{array}{c}\text { What size is your library } \\
\text { population base? }\end{array}$} \\
\hline $\begin{array}{c}\text { How important are the } \\
\text { following attributes of e- } \\
\text { book licenses for your } \\
\text { lihrary? - Triggers for } \\
\text { purchases of additional } \\
\text { copies based on user } \\
\text { demand (eg. hold requests) }\end{array}$ & Chi Square & $3.96^{*}$ \\
\cline { 3 - 4 } & Degrees of Freedom & 6 \\
\hline
\end{tabular}

"Note: The Chi-Square approximation may be inaccurate - expected frequency less than 5.

\begin{tabular}{|c|l|l|}
\cline { 3 - 3 } \multicolumn{2}{l|}{} & \multicolumn{1}{|l|}{$\begin{array}{c}\text { What size is your library } \\
\text { population base? }\end{array}$} \\
\hline $\begin{array}{c}\text { How important are the } \\
\text { following attributes of e- } \\
\text { book licenses for your } \\
\text { library? - Integration of } \\
\text { titles supplied by different } \\
\text { vendors through one } \\
\text { discovery interface }\end{array}$ & Degrees of Freedom & $9.52^{*}$ \\
\cline { 2 - 3 } & p-value & 6 \\
\hline
\end{tabular}

"Note: The Chi-Square approximation may be inaccurate - expected frequency less than 5. 


\section{BIBLIOGRAPHY}

Besen, S. M., \& Kirby, S. N. (2012). E-books and libraries: an economic perspective. http://www.ala.org/offices/sites/ala.org.offices/files/content/oitp/publications/booksstudies/e books libraries economic perspective.pdf

Brantley, P. (2012). 'You have two, maybe three years...' Publishersweekly.com. http://www.publishersweekly.com/pw/print/20121217/55131-you-have-two-maybe-threeyears.html.

Bridget Williams Books. (2011). 'Bridget Williams Books library e-book survey results'.

CULC/CBUC. (2012). Discussion document - eBooks and public libraries: discovery layers and purchasing directly from Canadian-based publishers.

http://www.culc.ca/cms lib/eBooks\%20and\%20Public\%20Libraries.pdf

Department for Culture, Media and Sport. (2013). An independent review of e-lending in public libraries in England.

https://www.gov.uk/government/uploads/system/uploads/attachment data/file/175318/ELe nding Review.docx

Digital Book World. (2013). 'Douglas County Libraries partners with OdiloTID to expand its library ebook model nationwide.' http://www.digitalbookworld.com/2013/douglas-countylibraries-partners-with-odilotid-to-expand-its-library-ebook-model-nationwide/

Digital Content \& Libraries Working Group. (2012). EBook business models for public libraries: a report from the American Library Association.

http://americanlibrariesmagazine.org/sites/default/files/EbookBusinessModelsPublicLibs A $\underline{\text { LA.pdf }}$

Enis, M. (2012a). 'Califa, DCL, Open Library make commitments to Smashwords' Library Direct.' The Digital Shift. http://www.thedigitalshift.com/2012/08/ebooks/califa-dcl-openlibrary-make-commitments-to-smashwords-library-direct/

---. (2012). 'Penguin ebook pilot test expands beyond NYC.' The Digital Shift. http://www.thedigitalshift.com/2012/10/ebooks/nypl-bpl-3m-officially-launch-penguin-pilottest/.

'FAQ'. (n.d.). Freading. http://freading.com/questions/index. 
Grigson, A. (2011). "An introduction to e-book business models and suppliers" in E-books in libraries: a practical guide. Eds Kate Price and Virginia Havergal. London: Facet Publishing. P19-35.

Hoffelder, N. (2012). "Hachette Joins the "I Hate Libraries" Club - Now Raising eBook prices Through the Roof.' The Digital Reader. Retrieved October 23, 2012, from http://www.the-digital-reader.com/2012/09/13/hachette-joins-the-i-hate-libraries-club-nowraising-ebook-prices-through-

the-roof/\#.UIZ4ocWTxh0

Indvik, L. (2013). 'Simon \& Schuster brings e-books to NYC libraries." Mashable. http://mashable.com/2013/04/15/simon-schuster-ebooks-nypl/

INFOdocket (2013). 'UPDATED: Macmillan announces details of library lending pilot.' Library Journal. http://www.infodocket.com/2013/01/24/macmillan-announces-details-oflibrary-lending-pilot/.

Kelley, M. (2012). 'With Axis 360, Baker \& Taylor establishes a foothold in the ebook distribution market.' The Digital Shift. http://www.thedigitalshift.com/2012/03/ebooks/withaxis-360-baker-taylor-establishes-a-foothold-in-the-ebook-distribution-market/.

Kolowich, S. (2012). 'Affection for PDA'. Inside Higher Ed.

http://www.insidehighered.com/news/2012/06/20/research-foresees-demand-driven-bookacquisition-replacing-librarians-discretion.

Maier, R. C., \& Russell, C. (2012). 'Warning: you are about to enter the ebook zone.' American Libraries, (E-Content Supplement to May/June 2012), 8-11. Retrieved from http://viewer.zmags.com/publication/f8ac9caa\#/f8ac9caa/10

Maloney, J. (2012). 'Libraries Cut E-Book Deal With Penguin.' The Wall Street Journal. Retrieved from

http://online.wsj.com/article/SB10001424052702304898704577479174051216172.html

'NZ e-book initiative: statistics statements' (2013). Internal NLNZ e-book initiative document.

'New Zealand e-book initiative project approach : Phase 1: September 2012-March 2013'. Presentation prepared for first stakeholder meeting for the initiative, November 2012. 
O Brien, D. R., Gasser, U., and Palfrey, J. (2012). E-books in libraries: a briefing document developed in preparation for a workshop on e-lending in libraries. Berkman Center Research Publication No. 2012-15. http://apo.org.au/sites/default/files/SSRNid2111396.pdf

Pewhairangi, S. (2011). 'Ebook Providers in New Zealand: OverDrive and Wheelers.' Finding Heroes. Retrieved October 22, 2012, from

http://findingheroes.co.nz/2011/07/26/ebook-providers-in-new-zealand-overdrive-andwheelers/

Public Library Online. (n.d.). 'Get Started'. http://publiclibraryonline.wordpress.com/getstarted/.

Vinjamuri, D. (2013). 'Simon \& Schuster tests ebook lending with New York Libraries.; Forbes. http://www.forbes.com/sites/davidvinjamuri/2013/04/15/simon-schuster-testsebook-lending-with-new-york-libraries/

von Hielmcrone, H. (2012). IFLA e-lending background paper. Retrieved from http://www.ifla.org/files/assets/clm/publications/ifla-background-paper-e-lending-en.pdf

Wallace, D.P. \& Van Fleet, C. (2012). Knowledge into action: research and evaluation in library and information science. Santa Barbara, CA: Libraries Unlimited.

Wheelers. (n.d.). 'eBook lending has changed for good.'

http://www.wheelers.co.nz/info/ebooks/.

Wildemuth, B. M. (2009). Applications of social research methods to questions in information and library science. Westport, CT: Libraries Unlimited.

Yelton, A. (2012). 'Ebooks Choices and the Soul of Librarianship.' The Digital Shift. Retrieved October 23, 2012, from http://www.thedigitalshift.com/2012/07/ebooks/ebookschoices-and-the-soul-of-librarianship/ 